\title{
Review of Maintenance and Repair Times for Components in Technological Facilities
}

\author{
Lee C. Cadwallader
}

November 2012

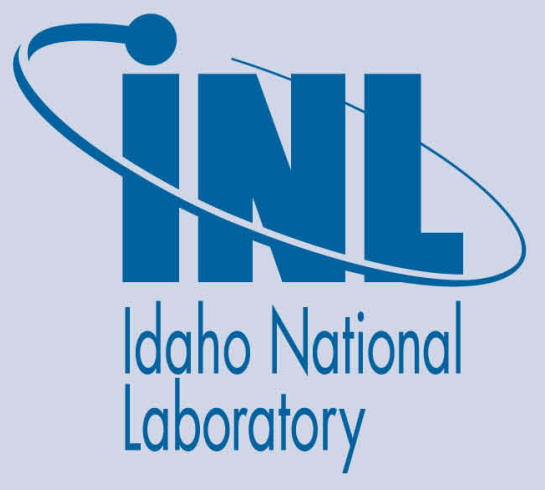

The INL is a U.S. Department of Energy National Laboratory operated by Battelle Energy Alliance 


\section{Review of Maintenance and Repair Times for Components in Technological Facilities}

Lee C. Cadwallader

November 2012

\section{Idaho National Laboratory \\ Experimental Programs \\ Idaho Falls, Idaho 83415}

http://www.inl.gov

Prepared for the

U.S. Department of Energy

Office of Science

Under DOE Idaho Operations Office

Contract DE-AC07-05ID14517 


\section{NOTICE}

This information was prepared as an account of work sponsored by an agency of the U.S.

Government. Neither the U.S. Government nor any agency thereof, nor any of their employees, makes any warranty, express or implied, or assumes any legal liability or responsibility for any third party's use, or the results of such use, of any information,

apparatus, product, or process disclosed herein, or represents that its use by such third party would not infringe privately owned rights. The views expressed herein are not necessarily those of the U.S. Nuclear Regulatory Commission. 



\begin{abstract}
ABS TRACT
This report is a compilation of some unique component repair time data and it also presents citations of more extensive reports where lists of repair times can be found. This collection of information should support analysts who seek to quantify maintainability and availability of high technology and nuclear energy production systems. While there are newer sources of repair time information, most, if not all, of the newer sources are proprietary and cannot be shared. This report offers data that, while older, are openly accessible and can serve as reasonable estimates of repair times, at least for initial studies. Some maintenance times are reported for radiation environments, and some guidance is given for multiplicative factors to use to account for work in contamination areas.
\end{abstract}




\section{SUMMARY}

A literature search was performed to identify sources of repair time data. Preference was given to historical data. When large reports or books were identified, these are cited and described in this report. These reports are openly accessible to analysts if needed. When smaller reports that were more difficult to obtain were located, these are described and excerpts of data values are given in this report due to the difficulty in securing copies. Thus, this report does provide some actual data as well as serve as a pointer to other, larger compilations of data.

The equipment to be repaired or maintained spans the realm of mechanical equipment, electrical distribution equipment, instrumentation, and electronics. Some equipment is large, such as that found in nuclear fission power plants and other energy production facilities. Other equipment is small, such as the instrumentation-size equipment found in a tritium facility. Data from the nuclear industry and from commercial and industrial sectors are cited here.

Several of the long-standing maintainability prediction approaches are described herein. These are largely based on the methods time measurement approach, where worker actions are divided down into the basic motions (reach, grasp, twist, etc.); a pre-determined time for each motion is assigned, then summed to give an overall time for the activity. Recent advances in this approach use virtual reality to aid in the definition of basic motions as well as account for accessibility to the repair location. These methods can be used when no historical data are available. 


\section{CONTENTS}

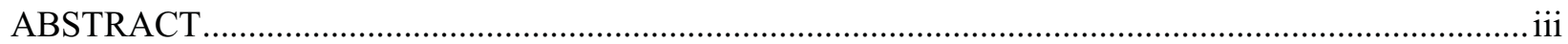

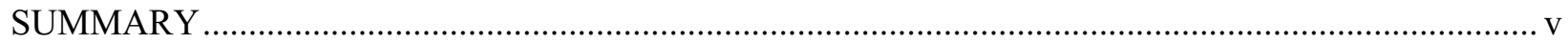

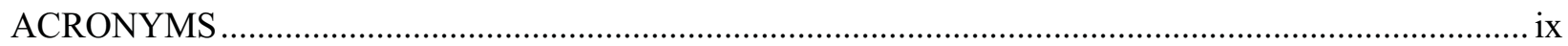

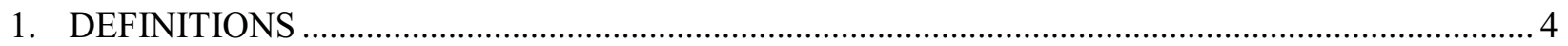

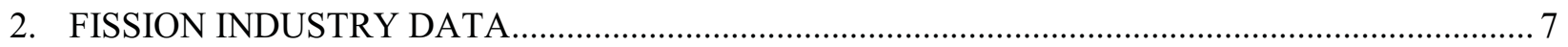

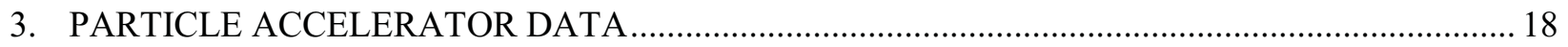

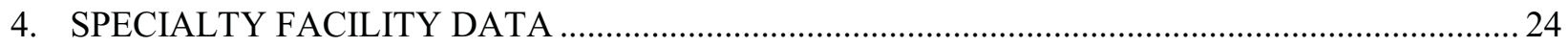

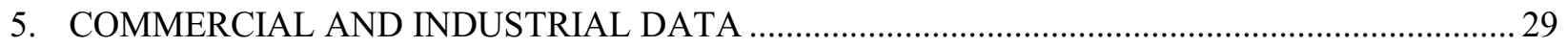

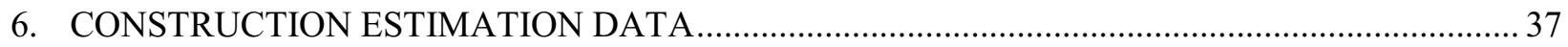

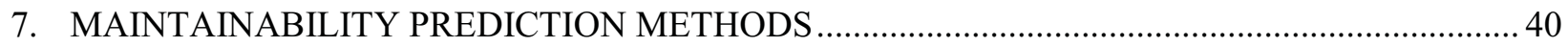

8. MAINTENANCE IN RADIATION FIELDS AND SOME MULTIPLIERS FOR

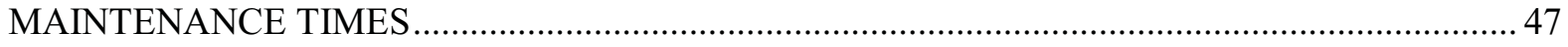

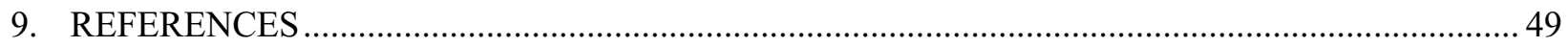

\section{FIGURES}

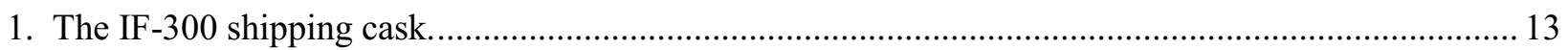

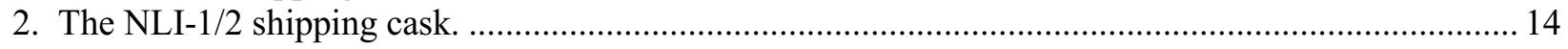

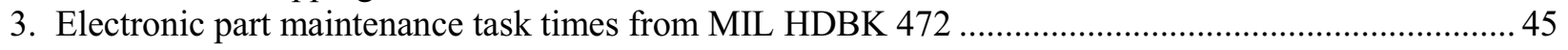

\section{TABLES}

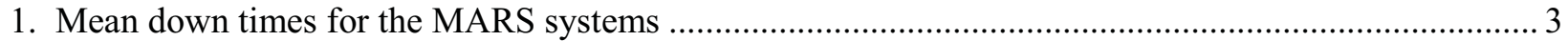

2. Some suggested times to use for logistics delays if no better data are available ................................. 6

3. Repair times for fission power plant systems based on rules at Yonggwang Units 5 and 6 (Yang

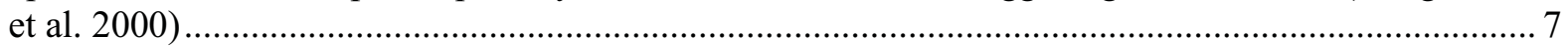

4. Suggested generic maintenance durations for advanced LWRs (EPRI 1999) ...................................... 8

5. On-site shop repair times for selected types of pumps in a fission power plant (Drago et al.

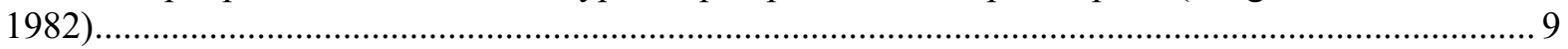

6. CM frequency and median repair time by valve type (Borkowski et al. 1983) ................................ 10

7. Repair times for several fission plant equipment items (Kahl and Borkowski 1985)......................... 10

8. CM and periodic testing in U.S. nuclear power plants (NRC 1975) ................................................. 11

9. Failure rate data and down times for multi-canister overpack handling machine (Swenson

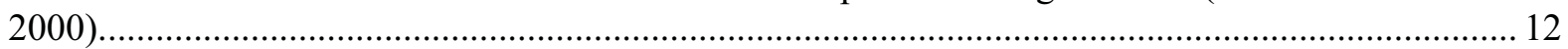

10. Failure and repair times from the Spallation Neutron Source....................................................... 18

11. System data at a high-power proton accelerator (Burgazzi and Pierini 2007) ................................. 19

12. Repair times from the International Linear Collider (Himel et al. 2007) ........................................ 19

13. Representative linear accelerator data (Linear Collider Steering Group 2004) ............................... 20

14. $805 \mathrm{MHz}$ superconducting RF system (Tallerico et al. 2001) ........................................................ 21

15. System-level repair times based on accelerator operations (Barlow and Liang 1977) ....................... 22

16. Repair times for tritium handling equipment (Hedley et al. 1990) .................................................. 25 
17. Chronology of events to replace an electromagnetic primary sodium sampling pump (Grygiel and McCargar 1986)

18. Reliability data for a gas-cooled fast breeder reactor (Bittermann and Wehling 1977)......

19. Reliability data of in-cell electro-mechanical manipulators and in-cell cranes (Stevenson 1987).

20. Typical repair data for water distribution components (Cullinane 1989)

21. Reliability of conventional wastewater treatment plant components (Schultz and Parr 1982)

22. Battery summary information (Hale and Arno 1999)

23. Repair times for computing equipment (Fricks and Trivedi 1998).

24. Diesel generator and gas turbine maintainability values (Smith et al. 1990)

25. Repair time database for jet fuel and airport fire equipment active repair times (Wright and Sattison 1987)

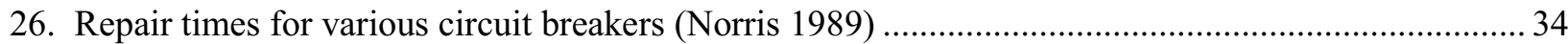

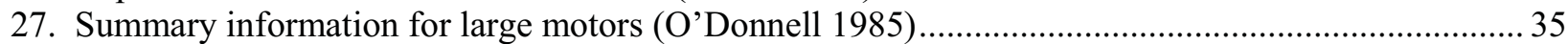

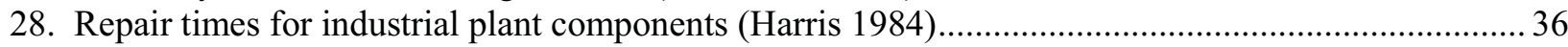

29. Instrument PM man-hours per year (Upfold 1971) ........................................................................ 37

30. Man-hour estimates for scaffolding installation and dismantling (Page 1999) .................................. 39

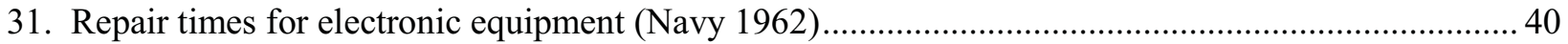

32. Technician experience factor used to determine staff knowledge (Navy 1962) ................................ 40

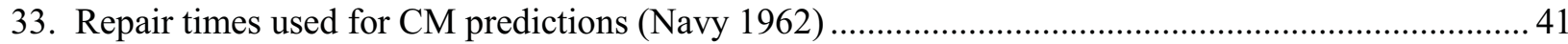

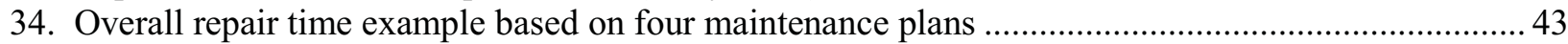

35. Repair times for electronics-based equipment (Defense 1966) .................................................... 44 


\section{ACRONYMS}

ALARA as low as reasonably achievable

ASME American Society of Mechanical Engineers

ATR Advanced Test Reactor

$\mathrm{CM} \quad$ corrective maintenance

EM electro-mechanical

ESRF European Synchrotron Radiation Facility

FNAL Fermi National Accelerator Laboratory

IEEE Institute of Electrical and Electronics Engineers

ILC International Linear Collider

INL Idaho National Laboratory

KEK Japanese acronym for National Laboratory for High Energy Physics

LANSCE Los Alamos Neutron Scattering Center

LINAC Linear Accelerator

LWR light water reactor

MARS Mirror Advanced Reactor Study

MDT mean down time

MTBF mean time between failures

MTM methods time measurement

MTTCM mean time to perform corrective maintenance

MTTM mean time to maintain

MTTR mean time to repair

NET Next European Torus

NRC U.S. Nuclear Regulatory Commission

PM preventive maintenance

RAMI reliability availability maintainability inspectability

RF radiofrequency

RS Robert Snow

TLC tighten, lube and clean

SKS Superconducting Koan Spectrometer

SLAC Stanford Linear Accelerator Center

SLC Stanford Linear collider

SNS Spallation Neutron Source 


\section{Review of Maintenance and Repair Times for Components in Technological Facilities}

Maintainability data, such as preventive maintenance (PM) times and corrective maintenance (CM) times for mechanical and electrical equipment, are needed in reliability-availability-maintainabilityinspectability (RAMI) studies that are performed on major facility systems to determine the availability of these systems and of the facility overall. These times are also very useful for estimating the occupational radiation exposure of the maintenance personnel at a facility.

A literature search was performed to identify sources of repair time data. This report will focus on the active repair time needed for craftsmen to restore a component to working order. Some of the literature found in the search gives only a few data points and those will be given here. Other literature sources give many pages of data; these will not be duplicated here. Instead, these data will be described, including keywords in the text, and the sources referenced for the analyst who would like to use those reports more fully. This report will also address PM times and inspection times when data values were found. These times are not well reported in the literature.

The analyst using this report should select the source plant or industry that is most similar to the application requiring data and then infer the repair times to the new application. The suggested approach is to keyword search this report for the component of interest, assess which industry is be the best inference to the system or facility under study, then use those data to develop an average value for use. The analyst is cautioned that none of the cited reports gave any substantial discussion of the spare part stocks or how the spare parts method used by the facility will affect the clock-hour repair times listed in the reports. Spare parts approaches range from keeping a large stock of spare parts in storage at the facility or contracting to provide the most likely spares needed within an established timeframe to using rush orders as needed or accepting longer down times due to long-lead time procurement of needed spares. For this reason, most repair times are given as the actual hands-on time to fix or replace components.

There are several recognized methods to obtain repair times. This report focuses on published data from plant operating experiences. Some of the cited documents in this report contain generic data values. The reader will note that the chapters are presented by industry because the data tend to be very industryspecific. Another method is to elicit repair time estimates from plant personnel since they have experience with the tasks and the work in general. A third method is repair time estimation using maintenance time methods, summing the times of individual actions the worker must take to complete a repair. Perhaps the best method is to evaluate historical data from facility operations experience. This is highly pertinent if the facility records available to the analyst are from the correct industry and if the facility has not changed its mission or equipment. Such evaluations can be exhaustive, so the literature search approach of determining if any finished data are available is a low-cost option that can serve the analyst well until more detailed data are needed.

The reader should note that the repair times from various studies and industries do not agree. In fact, in some cases they are widely dispersed. This is the nature of plant-to-plant and industry-to-industry variability in repair time data. Many factors can affect the repair times: subcontracted workers versus permanent staff at a plant, skill level of the workers involved in a task, number of workers assigned to the task, worker familiarity with the equipment, equipment accessibility, radiological conditions, toxicological conditions, environmental conditions (room temperature, humidity, lighting, etc.), severity spectrum of equipment failures that the staff are repairing, maintenance errors, quality of spare parts (spare part breakage upon a return-to-service test greatly extends the outage time) and perhaps other factors as well. There is also the issue that it is not clear that all cited documents are using the same definitions for mean down time and mean time to repair. 
There are not as many publications on maintainability data as there are on component failure rate data. A thorough literature search has been completed to identify those reports that carry actual time data on maintenance work, preferably from actual operations rather than estimation. There is also very little information reported on the time to perform inspection tasks. Operating facilities have all of this information on hand in their operating records, but these data have not reached the open literature. Some possible reasons are that each facility is a specific entity and the data are unique to that plant. Certainly issues such as the spare parts inventory kept on site versus ordering spares; the size, composition and training of the on-site maintenance team; and keeping an on-site staff versus contracting an off-site maintenance team all play a role in equipment outage times. Another reason might be concern over giving away confidential information that might aid a competitor. Generally, repair times are determined from prior experience at a facility, or by simulation of repair tasks.

Maintainability data, like failure rate data, can be inferred from similar applications. An important issue is being able to define how similar an application is before making a data inference. Some manufacturers will give suggested repair times as well as maintenance frequencies. When a facility is new and has no maintenance experience data, the personnel tend to use a combination of inference from similar facilities and manufacturer input to develop an initial maintenance plan and times for maintenance actions. This helps determine the maintenance staff size and composition, or the type of contract for an off-site maintenance company.

While the rest of this report focuses on component-level repair times, there are two studies that give system-level data for fusion systems: one large fusion study, the Next European Torus (NET), includes the system mean down time (see Table 1); some other estimates for the Mirror Advanced Reactor Study (MARS) are given in Table 2.

Table 1. Mean down times for NET fusion systems

\begin{tabular}{|l|l|l|}
\hline \multicolumn{1}{|c|}{ System } & \multicolumn{1}{|c|}{ Mean Down Time (hr) } & Comments \\
\hline First-wall system & 435 & without cooling \\
\hline & 57 & all cooling \\
\hline Blanket system & 435 & without cooling \\
\hline Vacuum vessel/shield & 2160 & without cooling \\
\hline Divertor plate & 435 & without cooling \\
\hline Toroidal field coil system & 1399 & \\
\hline Poloidal field coil system & 4200 & \\
\hline Cryostat & 24 & \\
\hline Radiofrequency system & 42 & \\
\hline Neutral beam injector system & 12 & \\
\hline Fuel pellet injection & 1 & \\
\hline Gas puffing & 1 & \\
\hline Vacuum pumping & 1 & \\
\hline Engineered safety features & 1.1 & \\
\hline Reactor auxiliary system & 34 & \\
\hline Nuclear fuel system & 24 & \\
\hline Cryogenic plant & 1 & \\
\hline Power transmission & 10 & \\
\hline Electric power supply & 4 & \\
\hline Central PIC system & 2.3 & \\
\hline Auxiliary systems & 1 & \\
\hline Structural systems & 8760 & \\
\hline $\begin{array}{l}\text { Notes: PIC stands for protection, instrumentation and control } \\
\text { These data came from the article: R. Bünde, 1988, "Reliability and Availability Assessments for } \\
\text { the Next European Torus," Fusion Technology, 14, pp. 197-217. }\end{array}$ \\
\hline
\end{tabular}


Table 1. Mean down times for the MARS systems

\begin{tabular}{|l|l|l|}
\hline \multicolumn{1}{|c|}{ System } & \multicolumn{1}{|c|}{$\begin{array}{c}\text { Failure rate } \\
(/ \mathbf{h r})\end{array}$} & \multicolumn{1}{c|}{$\begin{array}{c}\text { MTTR } \\
\text { (hr) }\end{array}$} \\
\hline Cryogenic & $1.1 \mathrm{E}-04 \quad 200$ \\
\hline Magnets & $4.0 \mathrm{E}-05$ & 1000 \\
\hline Direct convertor & $2.3 \mathrm{E}-04$ & 950 \\
\hline Plasma heating & $4.6 \mathrm{E}-04$ & 240 \\
\hline Neutral Beam & $1.4 \mathrm{E}-03$ & 240 \\
\hline Fueling & $1.1 \mathrm{E}-04$ & 200 \\
\hline Vacuum & $5.7 \mathrm{E}-05$ & 200 \\
\hline Shield & $2.3 \mathrm{E}-05$ & 240 \\
\hline Blanket & $1.7 \mathrm{E}-04$ & 240 \\
\hline Balance of plant & $2.5 \mathrm{E}-04$ & 240 \\
\hline Plant Instrumentation and controls & $2.0 \mathrm{E}-04$ & 48 \\
\hline $\begin{array}{l}\text { Notes: } \\
\text { These data came from Z. Musicki, C. W. Maynard, 1983, "The Availability Analysis of }\end{array}$ \\
Fusion Power Plants as Applied to MARS," Nuclear Technology/Fusion, 4, pp. 284-289. \\
\hline
\end{tabular}




\section{Definitions}

There are a number of definitions regarding maintenance times.

The mean down time (MDT) is the time from a component or system failing to perform its function to the component or system being returned to service. The MDT is often used at the system level, as in Tables 1 and 1. The MDT usually includes more than spare parts procurement as part of logistic delays. The logistics can include completing the maintenance work order, reviewing the maintenance work order, ensuring this maintenance activity will not endanger the plant or other personnel, a radiological safety review, an industrial safety review, and an environmental safety review. These can all take time, perhaps days.

The mean time to repair (MTTR) is usually referred to as the active repair time. This is the time when craftsmen are at the component, performing the actions to return the component to service. MTTR is sometimes referred to as the "hands-on" time. Some authors use MTTR to signify the "mean time to restore" the component to service. In that case, the meaning is the time from component failure to the time it is returned to service, so the mean time to restore includes the time for personnel access, diagnosis, procurement of spare parts or replacement component, the active repair time, the testing of the component, and then the component or system return to service time. Some authors use mean time to restore as an equivalent to the MDT.

The mean time to maintain (MTTM) is the time needed to perform PM tasks on the component.

The definition of preventive maintenance can vary. A broad definition would be "tighten, lube, and clean" or TLC, meaning to visit a component or equipment item and perform actions that enhance its ability to continue operation. A narrow definition is periodic inspection to alert plant personnel of possible breakdowns before the equipment fails. But PM can be more than that. The craftsmen will qualitatively examine the component, determine if it is running hotter than normal, and look for any telltale stains of evaporated coolant that has leaked from, or sprayed on to, the component. They look for lubricant leakage if lubricating oil or grease is used. They qualitatively assess operating aspects such as vibration, wear, and degradation of motion.

The mean time to perform corrective maintenance (MTTCM) is basically the mean time to repair, the active repair time.

Predictive maintenance is an approach that is sometimes called condition monitoring. This maintenance approach is quantitative measurement of vibration, thermography, oil analysis, and other factors that allow the maintainers to build a trend of when the particular mechanical component may be approaching failure. Sometimes, plant operators can contribute to predictive maintenance via control room instrumentation, such as tracking the bearing temperature of a large rotating machine as the bearing temperature slowly rises due to a faulty bearing. Some plants have had great success using predictive maintenance; a proper program can reduce CM time and allow planned equipment replacements instead of "run-to-failure" CM that can take the plant out of service. Other plants find it a costly proposition to have enough staff to collect all of the necessary data and analyze it for its trends. In this report, the acronym PM stands for PM rather than predictive maintenance.

This report will focus on the MTTR, or active repair times, for components. There are a few rough rules of thumb that might support an analyst in making an estimate of other times if the MDT is sought. In the ITER international project, the MTTR of a component is taken to mean the MDT. The MDT is composed of these times. 
CM includes

- Preparation time for workers after the failure has been recognized, including provisions for access, protective shielding, system cooldown to a safe state, etc.

- Failure isolation time (investigation to identify the failure)

- Spare parts or replacement item procurement time (logistics time)

- Adjustment or calibration time

- Fault correction time (the active repair time)

- Equipment checkout time (testing that the repair is adequate)

- Cleanup time

- Equipment return to service time (e.g., heatup). 
Table 2. Some suggested times to use for logistics delays if no better data are available

\begin{tabular}{|c|c|}
\hline CM Step & Suggestions for Estimate Guidance \\
\hline Preparation time & $\begin{array}{l}\text { This time can include steps for personnel safety, such as erecting } \\
\text { temporary radiation shielding or temporary ventilation for protection from } \\
\text { airborne chemicals. Scaffold assembly and disassembly times are given in } \\
\text { this report. As a first approximation, using the scaffold assembly times as } \\
\text { shielding erection times is probably adequate. } \\
\text { This time will also include "safing" the system for hands-on work. Safing } \\
\text { can include depressurization, cooldown (or warmup) to room temperature. } \\
\text { These times can be estimated from the design data. For example, the } \\
\text { ITER specification is that the cooling water systems have a } \pm 5 \mathrm{~K} / \mathrm{hr} \\
\text { heatup/cooldown rate for the tokamak. }\end{array}$ \\
\hline Failure isolation time & $\begin{array}{l}\text { This is finding the general, and then specific, location of the failed item. } \\
\text { This time is usually included in the repair time. }\end{array}$ \\
\hline $\begin{array}{l}\text { Troubleshooting } \\
\text { investigation }\end{array}$ & $\begin{array}{l}\text { This time includes the identification of possible causes of the failure and } \\
\text { any deficiencies in the equipment. This is usually included in the repair } \\
\text { time. }\end{array}$ \\
\hline Spare parts procurement & $\begin{array}{l}\text { An assumption is made based on fission power plant experiences. If a } \\
\text { spare part is in site stores, and it is a rush item it can be picked within } 8 \\
\text { clock hours. If the spare part is in site stores and it is a normal item it can } \\
\text { be picked in } 24 \text { clock hours. If the part must be ordered from a vendor, } \\
\text { then a rush order may take between } 24 \text { and } 72 \text { clock hours, and normal } \\
\text { delivery is assumed to require } 168 \text { hours to } 240 \text { clock hours. } \\
\text { Some parts will be known; for example if the staff member recognizing a } \\
\text { valve leak orders a seal kit when filing the work order for the repair, then } \\
\text { the kit arrives while preparations are being made to access the valve. }\end{array}$ \\
\hline Adjustment time & $\begin{array}{l}\text { This is the time to calibrate or otherwise prepare a part for installation. This } \\
\text { is assumed to be included in the repair time. }\end{array}$ \\
\hline Fault correction time & $\begin{array}{l}\text { This is part of the active repair time. The active repair time can be from } \\
\text { failure isolation to equipment checkout. These times are presented in this } \\
\text { report. }\end{array}$ \\
\hline Equipment checkout time & $\begin{array}{l}\text { The post-repair testing time is generally short duration, assumed to be } \\
\text { included in the repair time. }\end{array}$ \\
\hline Cleanup time & $\begin{array}{l}\text { This time is the removal of new part packaging, cleaning the area if the } \\
\text { work generated dirt or dust or other debris, and removal of shielding or } \\
\text { scaffolding. As a first approximation, use the setup time as the cleanup } \\
\text { time. }\end{array}$ \\
\hline $\begin{array}{l}\text { Equipment return to } \\
\text { service time }\end{array}$ & $\begin{array}{l}\text { As a first approximation, this would be the same amount of time as the } \\
\text { preparation time. }\end{array}$ \\
\hline
\end{tabular}




\section{Fission Industry Data}

Much of the fission industry data that has been openly published are somewhat older statistics. However, the maintenance times for many equipment items are probably not much different now than in the past. This is especially true for mechanical and electrical distribution equipment. The electronic equipment found in instrumentation and control systems continues advancements with built-in testing, self-diagnostics, and fault tolerant design so that maintenance and troubleshooting of these electronics are more likely to be smaller times now than in the past.

\section{J.-E. Yang, T.-Y. Sung, and Y. Jin, 2000, "Optimization of the Surveillance Test Interval of the Safety Systems at the Plant Level," Nuclear Technology, 132, pp. 352-365.}

This paper gives some system-level repair times for various fission power plant safety systems. The test interval is based on national rules used at Yonggwang Units 5 and 6 . The MTTRs are based on plant data. The costs given are believed to be representative of actual session costs for surveillance testing, PM restorative maintenance, and repair/replacement CM. The values are given in Table 3.

Table 3. Repair times for fission power plant systems based on rules at Yonggwang Units 5 and 6 (Yang et al. 2000)

\begin{tabular}{|l|c|c|c|c|c|}
\hline & \multirow{2}{*}{$\begin{array}{c}\text { System Test } \\
\text { Interval }\end{array}$} & \multirow{2}{*}{$\begin{array}{c}\text { MTTR } \\
\text { System Name }\end{array}$} & \multicolumn{3}{|c|}{ Average Session Costs (\$) } \\
\cline { 4 - 6 } & (wr) & Testing & PM & Repair \\
\hline Auxiliary Feedwater System & 4 & 16 & 50 & 200 & 30,000 \\
\hline Steam Removal System & 13 & 8 & 15 & 80 & 12,000 \\
\hline Bleed System & 53 & 8 & 15 & 80 & 12,000 \\
\hline High Pressure Safety Injection & 13 & 20 & 70 & 350 & 52,500 \\
\hline Low Pressure Injection & 13 & 28 & 70 & 350 & 52,500 \\
\hline Emergency Diesel Generators & 4 & 20 & 50 & 250 & 37,500 \\
\hline Service Water System & 4 & 17 & 40 & 400 & 60,000 \\
\hline Instrument Air System & 4 & 16 & 35 & 150 & 22,500 \\
\hline Safety Injection Tank & 53 & 8 & 50 & 200 & 30,000 \\
\hline
\end{tabular}

P. Samanta et al., 1994, Emergency Diesel Generator: Maintenance and Failure Unavailability, and Their Risk Impacts, NUREG/CR-5994, BNL-NUREG-52363, U.S. Nuclear Regulatory Commission (NRC), November.

This report gives some times of interest for the diesel generators at fission power plants:

- PM, MTTM $=24.6$ hours and an average of 5.5 sessions per diesel-year

- $\mathrm{CM}, \mathrm{MTTR}=23.3$ hours and an average of 3.3 sessions per diesel-year

- Periodic test as required in technical specifications, 2.2 hours average duration; times per year was not given but diesel generators are probably tested monthly. The data on testing were not as firm as the PM and CM data because some of the utility companies did not include testing data in the materials they returned to the report authors. 
ATV, 1992, Reliability Data of Components in Nordic Nuclear Power Plants, T-book, $3^{\text {rd }}$ edition, ATV Office and Studsvik, Vattenfall AB, S-16287 Vallingby, Sweden.

This small book gives some active repair times in hours by component failure mode for selected components from a total of fourteen nuclear power plants in Sweden and Finland. The dataset includes pumps, a variety of valves, rod drives, instruments, diesel generators, gas turbines, batteries, static rectifiers, static inverters, rotating converters, transformers, bus bars, switches, generator breakers, circuit breakers, and static converters.

H. R. Booth, F. J. Mollerus, J. L. Wray, 1992, “Faulted Systems Recovery Experience," NSAC-161, Nuclear Safety Analysis Center, Electric Power Research Institute, Palo Alto, California, May.

This report discusses fission power plant system recoveries. Therefore, the maintenance actions described this report are urgent activities. For valve recoveries, nearly all events showed recovery within 2 hours, and the predominant failure mode was the valve failing closed. The report stated that valves had among the shortest recovery times. In many cases, this was due to the valve being left in the wrong position or instrumentation moved the valve to the wrong position. The valve would readily be repositioned or the instrumentation was reset or bypassed.

Electric Power Research Institute (EPRI), 1999, Advanced Light Water Reactor Utility Requirements Document, Volume III, ALWR Passive Plant, revision 8, EPRI TR-016780-V3R8, Palo Alto, California, March, page A.A-27.

This report gave some suggested generic maintenance durations for use in advanced light water reactor (LWR) design studies. These are given in Table 4.

Table 4. Suggested generic maintenance durations for advanced LWRs (EPRI 1999)

\begin{tabular}{|l|l|}
\hline \multicolumn{1}{|c|}{ Maintenance Category } & \multicolumn{2}{c|}{$\begin{array}{c}\text { Mean duration } \\
\text { (hr) }\end{array}$} \\
\hline Short duration events such as repair of a motor operated valve & 10.8 \\
\hline Maintenance within the 72-hour plant operability limit & 20.9 \\
\hline Maintenance within the 7-day plant operability limit & 40.4 \\
\hline Maintenance with no plant operability limit & 116 \\
\hline
\end{tabular}

\section{S. Milivojevic, J. R. Riznic, 1989, "The Empirical Failure Rate and Repair Rate of PWR Primary Coolant Pumps," Reliability Engineering and System Safety, 24, pp. 267-273.}

This paper presents the study of over 500 pressurized water reactor main coolant pumps, e.g., $\approx 7 \mathrm{MW}$ motor power, and $350 \mathrm{Mg} /$ minute flow rate. The repair rate data showed that the active repair time, the MTTR, tended to decrease as pump life continued, from a high of $\approx 500$ hours in the first years of life to as low as 100 hours in later life. The analyst should note that these are large pumps that require a crane for lifting parts, may require scaffolds for worker access, and are in the containment building so radiological precautions are necessary for workers. However, the MTTR did not include the preparations for maintenance (i.e., temporary shielding, scaffolds, crane lift test, crane availability, etc.), just the actual repair time for the pump component.

International Atomic Energy Agency, 1988, Component Reliability Data for Use in Probabilistic Safety Assessment, IAEA-TECDOC-478, Vienna, October.

This report contains a broad selection of components, primarily mechanical and electrical with some instrumentation components, and presents plant-specific failure rate data from fission power plant risk 
assessments. There are also data from handbooks, operating experience reports, and other studies. Some of the failure rate entries have repair time values or ranges, but many entries do not give that information.

J. P. Drago, R. J. Borkowski, J. R. Fragola, J. W. Johnson, 1982, The In-Plant Reliability Data Base for Nuclear Plant Components: Interim Data Report-The Pump Component, NUREG/CR-2886, ORNL/TM-8465. December.

This report examines data records from selected fission power plants. Only one plant had maintenance records available for review. The data in Table 5 are from this report but are only the power plant's maintenance shop repair times. These times given do not include failure detection, diagnosis, pump removal to the shop, or pump reinstallation.

Table 5. On-site shop repair times for selected types of pumps in a fission power plant (Drago et al. 1982)

\begin{tabular}{|c|c|c|c|}
\hline \multirow[b]{2}{*}{ Pump Type } & \multicolumn{3}{|c|}{ Repair Time (hr) } \\
\hline & Minimum & Mean & Maximum \\
\hline Auxiliary diesel-driven feedwater pump & 1 & 7 & 40 \\
\hline Auxiliary turbine-driven feedwater pump & 2 & 16 & 67 \\
\hline Boric acid transfer pump & 1 & 11 & 48 \\
\hline Boron injection recirculation pump & 1 & 17 & 48 \\
\hline Centrifugal charging pump & 2 & 92 & 531 \\
\hline Circulating water pump & 2 & 53 & 240 \\
\hline Component cooling water pump & 3 & 14 & 128 \\
\hline Condensate pump & 1 & 65 & 985 \\
\hline Containment spray pump & 4 & 8 & 20 \\
\hline Diesel fuel oil transfer pump & 3 & 4 & 4 \\
\hline Fire pump, motor-driven & 1 & 9 & 40 \\
\hline Fire pump, diesel-driven & 1 & 9 & 24 \\
\hline Fire system jockey pump & 1 & 5 & 40 \\
\hline $\begin{array}{l}\text { Emergency lube oil pump for feedwater } \\
\text { pump turbine }\end{array}$ & 4 & & \\
\hline $\begin{array}{l}\text { Main lube oil pump for feedwater pump } \\
\text { turbine }\end{array}$ & 14 & & \\
\hline Positive displacement charging pump & 1 & 33 & 100 \\
\hline Reactor coolant pump & 2 & 55 & 300 \\
\hline Residual heat removal pump & 2 & 77 & 300 \\
\hline Safety injection pump & 4 & 37 & 280 \\
\hline Service water pump & 1 & 24 & 651 \\
\hline Service water booster pump & 1 & 10 & 40 \\
\hline Steam generator feed pump & 1 & 28 & 538 \\
\hline
\end{tabular}

\section{R. J. Borkowski, W. K. Kahl, T. L. Hebble, J. R. Fragola, J. W. Johnson, 1983, The In-Plant Reliability Data Base for Nuclear Plant Components: Interim Data Report-The Valve Component, NUREG/CR-3154, ORNL/TM-8647, September.}

This report analyzes were repair times available from one fission power plant. The data are given in Table 6. These are the active repair man-hours of maintenance staff, not actual clock hours. There is also 
some individual repair time data for pressurizer valves in Appendix $\mathrm{C}$ of the report. Most of the repair times are between 3 and 6 hours.

Table 6. CM frequency and median repair time by valve type (Borkowski et al. 1983)

\begin{tabular}{|c|c|c|c|}
\hline Valve Type & Operator Type & $\begin{array}{c}\text { Maintenance Frequency } \\
\text { (failures per } 1 E+06 \text { hours) }\end{array}$ & $\begin{array}{c}\text { Median } \\
\text { Repair Time } \\
\text { (man-hours) }\end{array}$ \\
\hline & Pneumatic & 7.61 & 8 \\
\hline & Others & 6.76 & 3 \\
\hline \multirow[t]{4}{*}{ Butterfly } & All & 9.64 & 4 \\
\hline & Pneumatic & 35.1 & 4 \\
\hline & Motor-driven & 28.2 & 4 \\
\hline & Others & 3.4 & 3 \\
\hline Check & All & 9.65 & 6 \\
\hline Diaphragm & All & 4.52 & 5 \\
\hline \multirow[t]{5}{*}{ Gate } & All & 17.6 & 6 \\
\hline & Pneumatic & 97.8 & 8 \\
\hline & Motor-driven & 62.0 & 4 \\
\hline & Hand & 28.5 & 4 \\
\hline & Others & 4.42 & 3 \\
\hline \multirow[t]{6}{*}{ Globe } & All & 17.2 & 4 \\
\hline & Pneumatic & 43.1 & 4 \\
\hline & Solenoid & 182.0 & 4 \\
\hline & Motor-driven & 48.0 & 2 \\
\hline & Hand & 25.1 & 10 \\
\hline & Others & 4.19 & 2 \\
\hline Relief/safety & All & 14.5 & 6 \\
\hline Directional & All & 14.6 & 3 \\
\hline \multirow[t]{4}{*}{ Control } & Pneumatic & 18.7 & 3 \\
\hline & Solenoid & 4.15 & 5 \\
\hline & Motor-driven & 68.2 & 2 \\
\hline & Others & 5.71 & 3 \\
\hline
\end{tabular}

\section{W. K. Kahl, R. J. Borkowski, 1985, The In-Plant Reliability Data Base for Nuclear Plant Components: Interim Report - Diesel Generators, Batteries, Chargers and Inverters, NUREG/CR-3831, ORNL/TM-9216, January 1985.}

This report has repair data from several plants. The repair times are active repair times for CM, that is, the hands-on portion of the work, and apparently do not include failure detection, diagnosis, or testing to return to service. The size and composition of the repair crews are not given. Table 7 gives some data from this report.

Table 7. Repair times for several fission plant equipment items (Kahl and Borkowski 1985)

\begin{tabular}{|c|c|c|c|}
\hline \multirow{2}{*}{ Equipment type } & \multicolumn{3}{|c|}{ Repair time (hr) } \\
\hline & Minimum & Mean & Maximum \\
\hline Diesel generator & 0.5 & 22 & 501 \\
\hline Battery (lead acid) & 1 & 19 & 200 \\
\hline Battery charger & 1 & 18 & 152 \\
\hline Inverter & 1 & 8 & 48 \\
\hline
\end{tabular}


Institute of Electrical and Electronics Engineers (IEEE), 1983, IEEE Guide to the Collection and Presentation of Electrical, Electronic, Sensing Component, and Mechanical Equipment Reliability Data for Nuclear-Power Generating Stations, IEEE-Std-500, New York.

This data compilation was reaffirmed in 1991, but was been withdrawn by IEEE in the late 1990s. However, it still carries some average repair time or MDT data for some of the components listed. Sometimes the repair fields are blank. This dataset is sometimes still used in reliability and risk work, and the repair times should be useful when they are given in the document.

NRC, 1975, Reactor Safety Study, an Assessment of Accident Risks in U.S. Nuclear Power Plants, Appendix III, "Failure Data," WASH-1400, NUREG-75/014, October.

There are some guidance values on CM and periodic testing in this appendix; they are reproduced in Table 8.

Table 8. CM and periodic testing in U.S. nuclear power plants (NRC 1975)

\begin{tabular}{|l|c|c|c|c|}
\hline \multicolumn{1}{|c|}{ Component } & $\begin{array}{c}\text { CM Time Range } \\
\text { (hr) }\end{array}$ & $\begin{array}{c}\text { MTTR } \\
\text { (hr) }\end{array}$ & $\begin{array}{c}\text { Test Time Range } \\
\text { (hr) }\end{array}$ & $\begin{array}{c}\text { Mean Test Time } \\
\text { (hr) }\end{array}$ \\
\hline Pumps & $2-400$ & 37 & $0.25-4$ & 1.4 \\
\hline Valves & $1-350$ & 24 & $0.25-2$ & 0.86 \\
\hline Diesel generator & $2-300$ & 21 & $0.25-4$ & 1.4 \\
\hline Instrumentation & $0.25-72$ & 7 & $0.25-4$ & 1.4 \\
\hline
\end{tabular}

\section{R. B. Calmus, 2002, Immobilized Low Activity Waste (ILAW) Disposal Preliminary RAM Analysis Report, RPP-13894, Rev. 0, CH2M Hill Hanford Group, Inc., December.}

This report gives some component mean time to restore to service times. Restoration for complex repairs to rolling stock (mobile cranes, dozers, compactors, etc.) had a mean time of 48 hours with a standard deviation of 18 hours and a lognormal distribution. An easy repair to a crane, such as replacement of a hook or bucket, 24 hours mean and 8 hour standard deviation of a lognormal distribution. A moderately complex repair to a crane, such as replacing an actuator, 48 hours mean and 18 hour standard deviation of a lognormal distribution. A complex repair to a crane, such as procuring and replacing a grapple device unique to the waste disposal function, was 720 hours mean and 360 hours standard deviation for a lognormal distribution. A software reboot or radiological control instrument replacement had a range of 1 to 6 hours, with mode of 2 hours. Restoring cameras, computers, or global positioning units have a 6 to 24 hour time span and a mode of 12 hours. Restoration of transformers, pumps needing complex maintenance that on-site personnel could accomplish has a span of 12 to 72 hours, with a mode of 24 hours. Trench liner repairs had a log-normal distribution with a 1440 hour mean and a standard deviation of 600 hours. Liquid waste storage tank restoration had a 48 hour mean and 16 hour standard deviation, with a lognormal distribution. A trolley hoist restoration had a 24 hour mean and an 8 hour standard deviation for a lognormal distribution.

\section{E. Swenson, 2000, FMEA/RAM Analysis for the Multi-Canister Overpack Handling Machine, SNF-6449, Fluor Hanford, June.}

This report addresses a machine that handles waste containers. Appendix D has a table of MDT values for valves, bearings, bellows, cables, cameras, trolley and bridge cranes, hoist equipment, air filters, control system logic components, lamps, motors, switches, valves, and other items related to cranes and hoists (see Table 9). The mean down time is clock hours from failure to restoration of service. Swenson gives some multipliers for restoring components that are in a contaminated area. A hoist brake on the hoist motor in a contamination area would be 2 (MDT), and that $2 \times$ estimate was also used for 
ducts, fan motors, orifice plugs, o-rings, and flow monitors. A factor of 1.5(MDT) was used for repairs of festoons for a trolley crane, seals, and tubes for helium gas flow that were being repaired inside contamination areas. The factor of 1.5 to 2 appears to be a reasonable increase to account for performing repair/replacement work in a contamination area that requires workers to suit up in anti-contamination clothing.

Table 9. Failure rate data and down times for multi-canister overpack handling machine (Swenson 2000).

\begin{tabular}{|l|c|l|}
\hline \multicolumn{1}{|c|}{ Component Description } & \multicolumn{1}{c|}{$\begin{array}{c}\text { Failure Rate } \\
(\mathbf{/ h r})\end{array}$} & \multicolumn{1}{|c|}{$\begin{array}{c}\text { Mean Down Time } \\
\text { (hr) }\end{array}$} \\
\hline Gas-operated valve, with operator & $9 \mathrm{E}-06$ & 48 \\
\hline Bearing & $9 \mathrm{E}-08$ & 168 \\
\hline Bellows & $1.6 \mathrm{E}-06$ & 168 \\
\hline Brake for hoist motor & $1.15 \mathrm{E}-05$ & 24 \\
\hline Circuit breaker & $1.2 \mathrm{E}-06$ & 12 \\
\hline HEPA filter & $3 \mathrm{E}-06$ & 48 \\
\hline Video camera & $5 \mathrm{E}-05$ & 72 \\
\hline Logic component & $\approx 1 \mathrm{E}-05$ & 12 \\
\hline Mechanical lock or pin & $2.6 \mathrm{E}-09$ & 48 \\
\hline O-ring & $1 \mathrm{E}-05$ & 24 \\
\hline Tube for helium & $1 \mathrm{E}-07$ & 48 \\
\hline Trolley drive gearbox & $2 \mathrm{E}-05$ & 72 \\
\hline
\end{tabular}

E. H. Smith, J. L. Liebenthal, H. D. Killian, K. R. Hoopingarner, and R. A. Moen, 1966, Crack in the Engineering Test Reactor Primary Cooling System, IDO-17158, Phillips Petroleum Company, Atomic Energy Division, Idaho Operations Office, U.S. Atomic Energy Commission, March.

The Engineering Test Reactor (operated from 1957 to 1981) discovered a primary coolant leak in a 0.9-m SS304L pipe on August 28, 1965. The pipe crack was "weeping" water coolant. The cooling system operated at $1.4 \mathrm{MPa}(200 \mathrm{psig})$ and about $43^{\circ} \mathrm{C}\left(110^{\circ} \mathrm{F}\right)$. A pipe crack had formed in a Y pattern around a $3.8-\mathrm{cm}$ tap for a gas probe. The cause of the crack was fatigue due to vibrational flutter of the $\approx 0.3$-m long gas probe wand in the primary coolant flow. A $0.24-\mathrm{m}$ by $0.16-\mathrm{m}$ pipe section containing the crack was weld cut out of the pipe and the edges of the rectangular hole were beveled, then ultrasonically and dye penetrant tested. A backing strip was arc welded on the inner edge of the opening. A patch was cut to dimension, beveled and rolled to pipe wall curvature, then arc welded into the pipe wall. The initial weld pass on the patch and the completed weld were radiographed and dye penetrant tested. The actual repair work began at 0800 hours on August 29 with cutting out the "window" in the pipe wall to remove the cracked section. A patch was fabricated and welded into place. The patch was completed and ready for pressure testing by 0800 on September 2. After pressure testing was completed, a reinforcing band was placed around the patch. The initial pipe repair task required 96 clock hours in a $0.8-1 \mathrm{mSv} / \mathrm{hr}$ radiation field. The documentation did not provide information on the number of workers involved. It is assumed that there were two non-destructive testing testers, two welders, and several health physics technicians standing by during work on the patch but only one person of each craft was in the radiation field at a time, so there is an estimate of 288 person-hours for this repair. Other personnel, such as the fire watch for hot work, machinists who fabricated the patch in the workshop, etc., could perform their work beyond the radiation field. This pipe repair activity was performed quite quickly, in 96 clock hours. 


\section{J. Hartman, D. D. Miller, 1992, Transportation Cask Decontamination and Maintenance at the Potential Yucca Mountain Repository, SAND89-7007, Sandia National Laboratories, April.}

There are some data on radioactive material transport cask tasks in this report. The IF-300 rail casks, shown in Figure 1, weigh 63,637 kg and measure $533.4 \mathrm{~cm}$ long and $162.6 \mathrm{~cm}$ outer diameter.

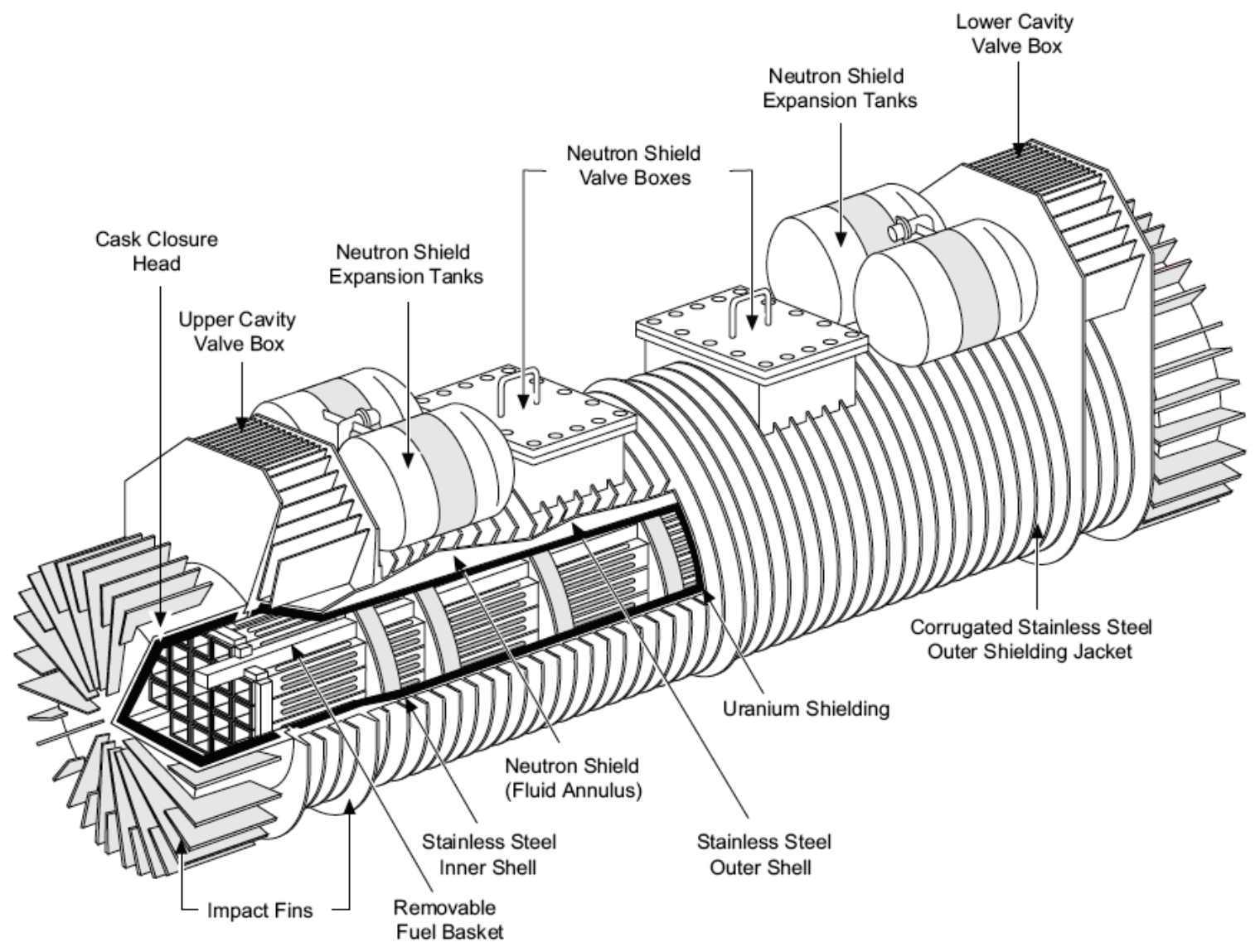

Figure 1. The IF-300 shipping cask.

Some times were given by IF-300 cask users:

- Two operators need about 30-40 minutes to take 40 radiological swipe samples of the cask exterior and 10 swipes of the cask carrier, then about 90 minutes to take the radiation counts of the set of 50 swipes.

- To fill the cask interior with water requires about 1 hour. The cask interior cavity dimensions are $457.8 \mathrm{~cm}$ long by $95.2 \mathrm{~cm}$ diameter. Flushing the cask cavity requires about 30 minutes with $113.5 \mathrm{~L} / \mathrm{min}(30 \mathrm{gal} / \mathrm{min})$ water flow, which is about one cask cavity volume $\left(3.26 \mathrm{~m}^{3}\right.$ or $\left.860 \mathrm{gal}\right)$.

- Two operators require 1 to 3 hours to remove the 32 bolts that hold the cask closure head. The operators use air wrenches. Two operators need about 30 minutes to replace an o-ring seal of a cask closure head. Helium leak testing requires about 15 minutes per valve on the cask and about 30 minutes for the closure head seal. Two operators require about 10 hours to decontaminate the interior of an empty cask before the cask is found suitable for shipping. They use spray wands with steam or 
decontamination chemical solution, and also manual scrubbing with long-handle scrub tools.

Removing a valve from the cask requires two operators about 1 hour; installing a new valve is about another hour.

The NLI-1/2 truck transport casks, shown in Figure 2, are $495.8 \mathrm{~cm}$ long, $119.6 \mathrm{~cm}$ outside diameter, and weigh $22,340 \mathrm{~kg}$. Two operators need about 15-20 minutes to unbolt and remove the outer closure head. The two operators require about 30 minutes to collect and analyze a gas sample from the cask interior cavity. The inner closure o-ring seal replacement typically requires about 15-20 minutes.

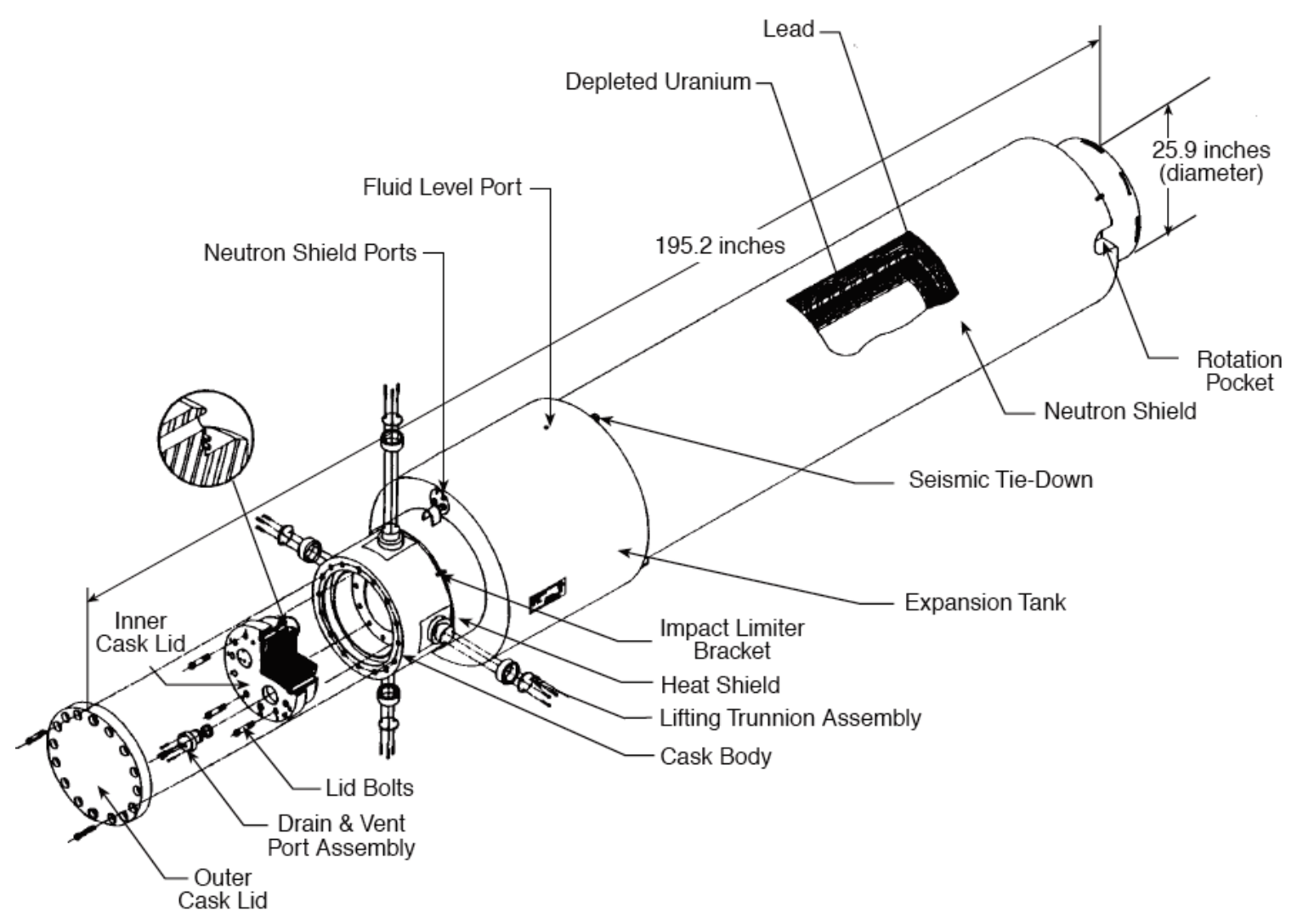

Figure 2. The NLI-1/2 shipping cask.

Taking 20-30 swipe samples of the exterior of an arriving cask takes two operators about 1 to 1.5 hours to obtain, count, and record the results. Removing the covers under the outer head, accessing the valves, and venting the cask cavity requires two operators for about 20-30 minutes. Then the cask cavity is filled with water, which requires 45 minutes; taking a sample of the water for analysis requires 45 minutes to obtain, count, and record the results. A cask cavity decontamination requires two operators working for 8 hours - half the time to decontaminate the surfaces with a steam lance and half the time to allow surfaces to dry then take swipes and analyze the swipes.

To wipe down the outer surface of an NLI $1 / 2$ cask manually with cloths takes two operators about 2 hours and includes swipe surveys. Cask unloading and turnaround time is generally $18-24$ hours in a hot cell. For casks lowered into a pool, cask unloading is usually 2-3 hours. Replacing an o-ring seal on the cask head involves removing the old seal, cleaning the seal groove, applying vacuum grease, installing the new seal-this is a 30 -min task for 2 operators. 
The NFS-100 cask weighs 43, $227 \mathrm{~kg}(95,100$ pounds) and is $3.25 \mathrm{~m}$ (128.3 in.) tall and $1.58 \mathrm{~m}$ (62.25 in.) in outer diameter. Unloading the cask in a fuel pool usually requires about 2 to 3 hours. Two operators can replace a closure head o-ring seal in about 30 minutes. Draining the cask of its $6.4 \mathrm{~m}^{3}$ $(1,700 \mathrm{gal})$ of water requires about 3 hours with the two $12.7 \mathrm{~mm}(0.5$-in.) drain valves. Using a siphon from the top of the cask to drain the water requires about 30 minutes.

Some data have been collected from the Advanced Test Reactor (ATR) at the Idaho National Laboratory. These data can be used to estimate inspection times and give some indications of repair times.

An issue of importance is weld inspections. It is assumed that any system welds in piping would be radiographed during construction (compliance with the ASME Boiler and Pressure Vessel Code). The inspections then switch to dye penetration testing and ultrasonic (volumetric) inspection performed periodically. At ATR, weld inspection is performed in two parts. The first part is dye penetrant. Note that ATR pipes do not have thermal insulation (no lagging). The technician wipes the pipe surface clean with dry rags, or with a cleanser if necessary, paints red dye on the weld with a brush or spray can, lets the dye penetrate for about 10 minutes, and wipes down any excess dye with another rag. Then a cleaner solution or plain water is used to remove residual surface dye and the weld is wiped down with rags again. After the solution or water is dried, a developer solution is sprayed on the pipe. The technician waits for 7-8 minutes and visually inspects for indications of dye in any cracks. If none are found, the white residue from the developer is wiped off to prepare the pipe weld for ultrasonic inspection. The dye process typically takes about 30 minutes for a $10 \mathrm{~cm}$-diameter pipe weld. This time can be scaled with the circumference of the pipe to be inspected. The technician, who usually works alone but has a buddy standing by outside the radiological area, can retreat from the radiation area during drying times, so radiological exposure is only about 10 minutes out of the 30 -minute process.

The second part of the periodic piping weld inspection is ultrasonic testing. Ultrasonic testing is performed by hand with a portable unit and requires less than 10 minutes per weld to access the weld in a 5 -cm diameter pipe. The process is to start the ultrasonic testing equipment, apply petroleum jelly on the weld for good contact with the probe, track the probe around the weld circumference, verify that the inspection data were good, wipe the jelly off the pipe, and leave the weld location. For a 10-cm diameter pipe, the ultrasonic test time would be 10-15 minutes/weld. Small piping under 5-cm diameter would take perhaps only 5-10 minutes per weld. For small diameter welds, the total technician exposure time is estimated to be 20 minutes per weld during a combined dye and ultrasonic testing inspection. Again, the inspection time can be scaled with the circumference of the pipe to be inspected.

Eddy current inspection of the heat exchanger tubes must be performed periodically. At ATR, eddy current inspection is performed every 10 years. A full inspection of all tubes in an ATR heat exchanger (containing about 1,300 tubes that are bent into U-tubes for about 92,000 square feet per heat exchanger) requires about 1.5 weeks. This is roughly 60 calendar hours because the crew of two inspectors does not work the back shifts. Thus, the time is 120 person-hours per heat exchanger. This figure would be scaled down for a smaller unit by the number of tubes or perhaps by the heat transfer surface area of the tube set.

In 1992, a small heat exchanger at ATR suffered a tube failure that resulted in tube-side liquid flowing into shell-side liquid. This small process heat exchanger had only been in service for about 8 years. Operators noted what appeared to be a $64 \mathrm{~L} / \mathrm{min}(17 \mathrm{gal} / \mathrm{min})$ leak from the process fluid to the lower pressure cooling fluid. For this heat exchanger unit neither the process fluid (tube side at 13 atmospheres [200 psi]) nor the cooling fluid (shell side) was radioactive, but the fluid was important to proper operation of the plant. The reactor was shut down and the affected heat exchanger (one of two side-by-side units) was identified. The heat exchanger was shut down and cooled down, then the stuffing box was accessed. The leaking stainless steel tube was located, plugged, and the three adjacent tubes were also plugged in case the damaged tube had inflicted damage on the neighboring tubes. The tube bundle was not pulled to inspect the failure (that action was deferred to a later time in favor of plant 
restart). The heat exchanger was scheduled for inspection during a future scheduled outage. The heat exchanger was pressure tested on both tube and shell sides and upon satisfactory results it was returned to service. Vibration and acoustical monitoring were also installed to allow for increased surveillance in case another tube failed. Accounting for overall plant cooldown, then heatup and power ascension time, approximately 150 calendar hours were needed for the tube repair activity and work planning. The exact number of workers involved in the activity is not known. It is assumed that there was one mechanic, one fitter, one testing technician for tube eddy current testing, and one foreman/supervisor.

Some other typical repairs at ATR have included a 7.6-cm (3-in.) pipe weld repair in 1992. When the small pipe leak was detected, the pipe was depressurized and cooled for personnel safety. Repair time took 80 calendar hours to cut out the old pipe section, check the pipe ends, weld in a new pipe piece, and radiograph the work. In 1995, a very small water pump began to leak at its volute seal - the gasket was "washing out." Replacement of the seal required 76 calendar hours of repair time. In 1998, a 2.5-cm (1-in.) pipe tee began to leak about $3.8 \mathrm{~L} / \mathrm{hr}$. Repair of the leaking weld required $\approx 104$ calendar hours for access, re-welding, radiography, and pressure test. The number of personnel is not known, but the area is a contamination zone, so a guess would be two welders; a radiation worker/laborer for decontamination, preparation, and area cleanup work; and a health physics technician. The supervisor and fire watch could observe from outside the zone.

Large equipment overhauls at ATR have included the four, 0.9-m (36-in.) diameter check valves in the primary coolant system. During a plant outage, these valves were disassembled, decontaminated, inspected; the valve disk pins were surface re-hardened; the dash pot assemblies were cleaned and inspected for corrosion; the valve case was non-destructive test inspected; then the valves were reassembled and the casing bolts torqued. The valves were leak checked and functionally tested, then declared operable again. The four valves were isolated in September 25, 1995, and then drained. Once dry, they were disassembled and parts laid down on the floor near the valves. Decontamination was performed, then interior inspection. Clevis units and hinge pins were hard surfaced. The valve case seals were changed and the valves reassembled. The valve bolts were retorqued and the valves were re-flooded for leak testing. This was accomplished for all four valves in a total of about 213 calendar hours. Thus, the overhaul of one large check valve would have required about 53.5 calendar hours with a crew of four workers (mechanics, fitters, and health physics technicians for survey and decontamination tasks).

In 1997, a small, $40 \mathrm{hp}$ electric-motor driven centrifugal pump, 4,700 gal $/ \mathrm{min}$ water flow at ATR required shaft seal changeout. The pump shaft is horizontal. During a planned reactor outage, the pump was shut down and isolated. The mechanic removed the pump top case and wrapped it in plastic to contain contamination left behind from evaporated coolant water. Radiological smear samples in the dry pump casing read $50 \mathrm{mrem} / \mathrm{hr}$, so work was suspended until a new radiation work permit and as low as reasonably achievable (ALARA) review could be completed. Work stopped while waiting for the new paperwork. When work resumed, the new seals were placed and the pump case top rebolting began. Rebolting the pump casing top was completed and a pressure test took place. The test failed; another set of new seals were needed. A day later, seal replacement tasks were under way. Work continued with a leak check that showed a $0.47 \mathrm{~L} / \mathrm{min}(1 \mathrm{pint} / \mathrm{min}$ ) leak (too high). Another 2 hours of labor were needed to correct the new seal leak problem. The total task time was $4.75+8.5+8+5+2$ hours for two seal installations, or $\approx 14$ hours per seal for two mechanics in a task that spanned 8 calendar days. The companion pump unit seal replacement completed testing in 1 day, for a total time of 9 clock hours with a crew of two mechanics. Thus, three pump shaft seal replacements required on average $\approx 12$ hours each, for two workers in each case. But this similar work on two companion pumps shows the variability in repair time data.

In 1998, several pumps were replaced or given major overhauls at the reactor. A $75 \mathrm{~kW}(100 \mathrm{hp})$, $1.1 \mathrm{~m}^{3} / \mathrm{min}$ (300 gal/min) pump was overhauled. The impeller rings had bound up, seizing the shaft and halting the impeller. The pump was completely disassembled, new parts installed, and it was returned to service in 3.5 calendar months after labor by an untracked number of workers. This was not a high 
urgency replacement because ATR was in a long outage for other reasons and there was a redundant pump available to meet any needs during the outage. Another pump was replaced in 1998 . The $30 \mathrm{~kW}$ (40 hp) pump and its motor were replaced over 14 days (336 hours) using an untracked number of workers. This was a major task but was not pursued 24-hours per day; there were some lulls in the task as workers were drawn away to perform other tasks during the plant outage. A time less than 14 days to replace a medium-sized pump and its motor is an initial estimate for a replacement time at a small reactor facility. In comparison, we note in Section 4 that replacing a small sodium electromagnetic pump required 37 days.

In 2000, a heat exchanger sprung a shell leak at a weld. The leak was discovered at on March 27. Steps were taken to reduce the water leakage from the shell side. On March 28, carpenters began erecting scaffolds to access the leak in the 10 to $100 \mathrm{mrem} / \mathrm{hr}$ radiation field. Any known or surveyed hot spots (i.e., $>1 \mathrm{rem} / \mathrm{hr}$ ) required sheets of temporary lead shielding to be placed for personnel protection. The ATR approach is to administratively limit the temporary shield placement task so the task exposure is below a safe value, such as $<100$ mrem dose for the task. Scaffolding placement was about 13 hours of work for two carpenters. By March 30 the heat exchanger had been completely drained in preparation for weld repair. Repairs began on March 31, and the weld was completed, cooled, inspected, and radiographed that day. This was 7.5 calendar hours for two welders with 0.5 hour for one radiographer to position equipment, shoot the weld, and check the results. The heat exchanger leak repair required 52 person-hours for scaffold setup and takedown, 15 person-hours for welders, and 0.5 person-hours for radiography. Health physics technicians surveyed the area before the work began ( 0.5 person-hour), and a fire watch was needed during and after the hot work (16 person-hours). It is noted that by Idaho National Laboratory (INL) procedure, parts weighing $22 \mathrm{~kg}$ or more require a chain hoist or other mechanical lifting apparatus. If similar rules are in force for fusion facilities, then portable lifting equipment must also be staged to support the maintenance replacement activity.

These maintenance times from ATR are point estimates from individual activities at a single nuclear facility. They are not good statistical average times for such activities, and the urgency of repair was not well defined in all cases; it was inferred from the documentation. Nonetheless, these values are indicative of the order of magnitude of time needed to perform major equipment repairs and replacements (e.g., hours to days to weeks). 


\section{Particle Accelerator Data}

Particle accelerators offer some advantages for reliability and maintainability work. These devices use large numbers of components (perhaps thousands of one component type) and many of the larger machines operate for several thousand hours each year. Therefore, operating experience data from these machines tend to yield good statistics. Searches of machine operations papers in particle accelerator conferences have yielded some MTTR data on components similar to fusion. These components include cryogenic plants and heating systems such as klystron systems. Fusion uses gyrotrons for electron cyclotron heating and klystrons for lower hybrid heating.

On July 3, 2012, Dr. G. Dodson at the Spallation Neutron Source (SNS) at Oak Ridge National Laboratory provided some data on failures and repair times, including the number of technicians needed to perform the repair. Some of these data are given in Table 10. In the SNS spreadsheet, some of the data come from published works on accelerator operations, e.g., a paper by Tallerico et al, 2001. That paper is discussed later in this chapter.

Table 10. Failure and repair times from the Spallation Neutron Source

\begin{tabular}{|c|c|c|c|}
\hline $\begin{array}{c}\text { Accelerator System } \\
\text { Component }\end{array}$ & $\begin{array}{l}\text { Failure Rate } \\
\text { (/hr) }\end{array}$ & Repair Personnel & $\begin{array}{l}\text { MTTR } \\
\text { (hr) }\end{array}$ \\
\hline \multicolumn{4}{|l|}{ Ion Source Subsystem } \\
\hline Antenna feedthrough & $2.5 \mathrm{E}-05$ & 2 & 1.0 \\
\hline Turbopump & $1.0 \mathrm{E}-05$ & 2 & 1.0 \\
\hline Scroll pump & $5.0 \mathrm{E}-05$ & 2 & 1.0 \\
\hline Gate valve & 1.0E-05 & 2 & 4.0 \\
\hline Vacuum gauge & $1.0 \mathrm{E}-05$ & 1 & 4.0 \\
\hline \multicolumn{4}{|l|}{$\begin{array}{l}\text { Radiofrequency Quadrupole } \\
\text { System }\end{array}$} \\
\hline Vacuum feedthrough leak & $5.0 \mathrm{E}-08$ & 1 & $4.0+2 \mathrm{hr}$ delay \\
\hline Cryo compressor failure & $1.0 \mathrm{E}-05$ & 1 & $4.0+2 \mathrm{hr}$ delay \\
\hline Cryopump failure & 2.8E-05 & 2 & $1.0+2 \mathrm{hr}$ delay \\
\hline Klystron, $2.5 \mathrm{MW}, 402.5 \mathrm{MHz}$ & 2.0E-05 & 3 & 3.5 \\
\hline Klystron window fracture & $1.0 \mathrm{E}-05$ & 2 & $12+12 \mathrm{hr}$ delay \\
\hline \multicolumn{4}{|l|}{ LINAC Cryoplant } \\
\hline Warm compressor & $1.55 \mathrm{E}-04$ & 2 & 8.8 \\
\hline 4.5 Kelvin Cold box & 1.87E-04 & 2 & 8.8 \\
\hline Turbine expander & 3.29E-05 & 2 & 8.8 \\
\hline 2.1 Kelvin Cold box & 3.88E-04 & 1 & 8.8 \\
\hline \multicolumn{4}{|l|}{ LINAC Diagnostics } \\
\hline Current monitor & 1.0E-06 & 1 & 2.0 \\
\hline Wire scanner & $1.0 \mathrm{E}-06$ & 1 & 2.0 \\
\hline
\end{tabular}

L. Burgazzi, P. Pierini, 2007, "Reliability Studies of a High-power Proton Accelerator for Accelerator-driven System Applications for Nuclear Waste Transmutation," Reliability Engineering and System Safety, 92, pp. 449-463.

This paper discusses LINAC machines and gives some MTTRs that were inferred from parts count analysis. For a radiofrequency (RF) system with a standard mission time of 168 hours, the MTTR for RF transmitters, high voltage power system, low level RF, power amplifiers, and power components are all 4 hours. This refers to clock hours. For the systems at a facility some other data were given as shown in Table 11. MTBF stands for mean time between failures. 
Table 11. System data at a high-power proton accelerator (Burgazzi and Pierini 2007)

\begin{tabular}{|l|l|c|c|}
\hline \multicolumn{1}{|c|}{ System } & \multicolumn{1}{|c|}{ Subsystem } & $\begin{array}{c}\text { MTBF } \\
\text { (hr) }\end{array}$ & $\begin{array}{c}\text { MTTR } \\
\text { (hr) }\end{array}$ \\
\hline Injector & Proton source & 1,000 & 2 \\
\hline & RF quadrupole & 1,200 & 4 \\
\hline & $\begin{array}{l}\text { Normal conducting } \\
\text { drift tube LINAC }\end{array}$ & 1,000 & 2 \\
\hline Support systems & & & \\
\hline & Cryoplant & 3,000 & 10 \\
\hline & Cooling system & 3,000 & 2 \\
\hline & Control system & 3,000 & 2 \\
\hline & & & 1 \\
\hline Beam delivery system & Magnets & $1,000,000$ & 1 \\
\hline & Power supplies & 100,000 & \\
\hline
\end{tabular}

T. Himel, J. Nelson, N. Phinney, M. Ross, 2007, “Availability and Reliability Issues for ILC," Proceedings of the Particle Accelerator Conference, Albuquerque, NM, pp. 1966-1969. Available for free download at accelconf.web.cern.ch.

The authors at the Stanford Linear Accelerator Center (SLAC) wanted to predict the operating availability of a new accelerator design called the International Linear Collider (ILC). They obtained data from the Stanford Linear Accelerator Center to use in their analysis. These data are given in Table 12.

Table 12. Repair times from the International Linear Collider (Himel et al. 2007)

\begin{tabular}{|c|c|c|c|}
\hline Component & $\begin{array}{c}\text { MTBF } \\
\text { (hr) }\end{array}$ & $\begin{array}{c}\text { MTTR } \\
\text { (hr) }\end{array}$ & Comments \\
\hline Water cooled magnet & $1,000,000$ & 8 & $\begin{array}{l}\text { Average from Stanford Linear collider (SLC), } \\
\text { some magnet families had } \\
\text { MTBF }>13,000,000 \mathrm{hr}\end{array}$ \\
\hline Air cooled magnet & $10,000,000$ & 2 & SLC \\
\hline $\begin{array}{l}\text { Superconducting } \\
\text { magnet }\end{array}$ & $10,000,000$ & 472 & $\begin{array}{l}\text { MTBF is } 10 \text { times the Tevatron dipole magnet } \\
\text { as the ILC magnets are lower current; a failed } \\
\text { superconducting quad would be turned arounc } \\
\text { in } 2 \mathrm{hr} \text { as a kludge repair }\end{array}$ \\
\hline Magnet power supplies & 50,000 & 2 or 4 & $\begin{array}{l}\text { SLAC and FNAL average; larger MTTR is for } \\
\text { large, not easily replaced power supplies }\end{array}$ \\
\hline Electronics modules & 100,000 & 1 & Average over many types of modules \\
\hline Water flow switch & 250,000 & 1 & SLAC data \\
\hline Damping ring klystron & 30,000 & 8 & SLAC data \\
\hline
\end{tabular}

U.S. Linear Collider Steering Group, 2004, U.S. Linear Collider Technology Options Study, prepared by the Accelerator Sub-committee, Linear Collider Option Task Forces, March 4, available at http://www.slac.stanford.edu/xorg/accelops/

This report gives representative data on MTBF and MTTR for accelerator components. Table 13 below gives these data. The MTTR was defined as the time from when personnel have access to the component until the component is repaired. The MTTR includes travel time (which can be significant in a large accelerator tunnel), but not the time for the accelerator to cool down before tunnel access is allowed, and the MTTR does not include the time to turn on and tune up the accelerator (presumably this 
means the component testing for adequate repair is not included). The MTBF as stated to be the average time between component failures assuming normal PM is performed. The MTBF does not include infant mortality failures; these are steady-state average values.

Table 13. Representative linear accelerator data (Linear Collider Steering Group 2004)

\begin{tabular}{|c|c|c|}
\hline Component Description & $\begin{array}{c}\text { MTBF } \\
\text { (hr) }\end{array}$ & $\begin{array}{c}\text { MTTR } \\
\text { (hr) }\end{array}$ \\
\hline Water cooled magnet & $1 \mathrm{E}+06$ & 8 \\
\hline Superconducting magnet & $1 \mathrm{E}+07$ & $\begin{array}{l}2 \text { for quad retune, } \\
472 \text { for superconducting quad }\end{array}$ \\
\hline Corrector or trim magnet & $1 \mathrm{E}+07$ & $\begin{array}{l}0.5 \text { for retune } \\
2 \text { for repair }\end{array}$ \\
\hline Power supply & $2 \mathrm{E}+05$ & $\begin{array}{l}2 \text { for normal unit } \\
4 \text { for large unit }\end{array}$ \\
\hline Power supply controller & $1 \mathrm{E}+05$ & 1 \\
\hline $\begin{array}{l}\text { Magnet flow switch for water cooled } \\
\text { magnet }\end{array}$ & $2.5 E+05$ & 1 \\
\hline $\begin{array}{l}\text { Vacuum mechanical device (devices } \\
\text { that move into the beamline; stoppers } \\
\text { or profile monitors) }\end{array}$ & $1 \mathrm{E}+05$ & 8 \\
\hline $\begin{array}{l}\text { Vacuum pump (type not given, but } \\
\text { every } 100 \mathrm{~m} \text { around the accelerator } \\
\text { ring-probably getter pumps) }\end{array}$ & $1 \mathrm{E}+07$ & 4 \\
\hline Vacuum pump power supply & $1 \mathrm{E}+05$ & 1 \\
\hline Vacuum valve & $1 \mathrm{E}+06$ & 4 \\
\hline Vacuum valve controller & $1.9 \mathrm{E}+05$ & 2 \\
\hline Beamline cooling water pump & $1.2 \mathrm{E}+05$ & 4 \\
\hline $\begin{array}{l}\text { Beamline cooling water pump } \\
\text { instrumentation }\end{array}$ & $3 \mathrm{E}+04$ & 2 \\
\hline Water flow switch & $2.5 \mathrm{E}+05$ & 1 \\
\hline $\begin{array}{l}\text { Beam position monitor, readout } \\
\text { module failure only }\end{array}$ & $1 \mathrm{E}+05$ & 1 \\
\hline Wire scanner, laser type & $1 \mathrm{E}+05$ & 2 \\
\hline Klystron, damping ring & $3 E+04$ & 8 \\
\hline Klystron, warm LINAC & $2.5 E+04$ & 8 \\
\hline Klystron, cold LINAC & $4 \mathrm{E}+04$ & 8 \\
\hline Klystron power supply, damping ring & $5 \mathrm{E}+04$ & 4 \\
\hline Low level RF controls & $1 \mathrm{E}+05$ & 1 \\
\hline Klystron pre-amplifier & $1 \mathrm{E}+05$ & 1 \\
\hline Klystron vacuum gauge & $1 \mathrm{E}+05$ & 1 \\
\hline Klystron vacuum pump & $1 \mathrm{E}+07$ & 8 \\
\hline Klystron vacuum pump power supply & $1 \mathrm{E}+05$ & 1 \\
\hline $\begin{array}{l}\text { Superconducting RF cavity cryo } \\
\text { vacuum leak }\end{array}$ & $1 \mathrm{E}+05$ & 8 \\
\hline $\begin{array}{l}\text { Superconducting RF cavity cryo } \\
\text { vacuum failure }\end{array}$ & $3 \mathrm{E}+05$ & 8 \\
\hline $\begin{array}{l}\text { Damping ring klystron water cooling } \\
\text { pump }\end{array}$ & $1.2 \mathrm{E}+05$ & 4 \\
\hline $\begin{array}{l}\text { Damping ring klystron water pump } \\
\text { instrumentation }\end{array}$ & $3 \mathrm{E}+04$ & 2 \\
\hline Water flow switch & $2.5 \mathrm{E}+05$ & 1 \\
\hline $\begin{array}{l}\text { High power (>0.5 MW) electrical } \\
\text { distribution circuit }\end{array}$ & $3.6 \mathrm{E}+05$ & 4 \\
\hline
\end{tabular}


Table 13. (continued)

\begin{tabular}{|l|c|l|}
\hline \multicolumn{1}{|c|}{ Component Description } & \multicolumn{1}{|c|}{$\begin{array}{c}\text { MTBF } \\
\text { (hr) }\end{array}$} & $\begin{array}{c}\text { MTTR } \\
\text { (hr) }\end{array}$ \\
\hline $\begin{array}{l}\text { Low power (50 kW to 0.5 MW) } \\
\text { electrical distribution circuit }\end{array}$ & $3.6 \mathrm{E}+05$ & 2 \\
\hline $\begin{array}{l}\text { Sitewide control system, such as } \\
\text { Machine Protection System or }\end{array}$ & $2.5 \mathrm{E}+03$ & 5 \\
Personnel Protection System & & 2 \\
\hline Sector controls & $1 \mathrm{E}+06$ & 1 \\
\hline Local controls & $1 \mathrm{E}+05$ & 1 \\
\hline Local klystron controls & $1 \mathrm{E}+05$ & 1 \\
\hline Personnel Protection System controls & $1 \mathrm{E}+05$ & 1 \\
\hline
\end{tabular}

L. Hardy, 2002, "Accelerator Reliability - Availability," Proceedings of the $8^{\text {th }}$ European Particle Accelerator Conference (EPAC 2002), June 3-7, Paris, France, paper WEXLA001. Available for free download at accelconf.web.cern.ch.

This paper discusses the overall operational availability of several accelerator facilities, including the Los Alamos Neutron Scattering Center (LANSCE) and the European Synchrotron Radiation Facility (ESRF). In the paper, it is stated that the mean time to replace a totally failed klystron is 8 hours at ESRF. The ESRF klystrons are $352.2 \mathrm{MHz}, 1 \mathrm{MW}$-continuous wave units that operate in a cycling mode of 10 Hz. These klystrons are similar in power to the plasma heating units specified for ITER, and the data point may be useful for fusion units.

\section{P. Tallerico, D. Rees, and D. Anderson, 2001, "An Availability Model for the SNS Linac RF} System," Proceedings of the 2001 Particle Accelerator Conference, Chicago, Illinois. Available for free download at accelconf.web.cern.ch.

This paper discussed the availability of a RF heating system, using SNS and Los Alamos accelerator data. The Los Alamos accelerator followed either a 4 or 8 hour scheduled repair session each week, and the authors assumed that spare parts were stocked so that they could replace any unit at will. Some data from this paper are given below in Table 14 .

Table 14. $805 \mathrm{MHz}$ superconducting RF system (Tallerico et al. 2001)

\begin{tabular}{|l|c|c|}
\hline \multicolumn{1}{|c|}{ Component } & $\begin{array}{c}\text { MTBF } \\
\text { (hr) }\end{array}$ & $\begin{array}{c}\text { MTTR } \\
\text { (hr) }\end{array}$ \\
\hline Klystron & 50,000 & 4.5 \\
\hline Wave guide & 150,000 & 3.0 \\
\hline Load & 75,000 & 3.0 \\
\hline Circulator & 50,000 & 3.0 \\
\hline Converter/modulator & 22,600 & 4.0 \\
\hline Transmitter & 5,600 & 3.0 \\
\hline Window & 100,000 & 24.0 \\
\hline Low level RF controls & 100,000 & 2.0 \\
\hline
\end{tabular}


K. Aoki and Y. Doi, 2002, "Reliability of the Cryogenic System for a Large Superconducting Spectrometer Magnet-SKS," Proceedings of the Nineteenth International Cryogenic Engineering Conference (ICEC-19), Grenoble, France, pp. 137-140.

The authors of this paper discussed 11 years of maintenance data for the 300-W liquid helium cryogenic system for the Superconducting Koan Spectrometer (SKS) on the KEK synchrotron at Tsukuba, Japan. KEK is a Japanese acronym for National Laboratory for High Energy Physics. The authors examined 163 failure events over 11 years of operations and 77 of these events required repairs. They used three repair event categories - light failure where the repair goes smoothly and operation restarts within the scheduled operation period, middle-light failure where repair requires more time and repair takes time beyond the scheduled operation period, and serious failure where the failure stops operation and the system cannot be operated for a long time duration due to the repair requiring time. Of the 77 failures that stopped operation, 63 were light failures, 13 were middle-light failures, and 1 was a serious failure. The serious failure was not well described but it required hundreds of hours to repair. The mean repair rate was $2.1 \mathrm{E}-02 / \mathrm{hr}$, or an MTTR $=48$ hours for the cryogenic system. The SKS cryogenic system MTTR was 7 times greater than comparable data for the TRISTAN accelerator's cryogenic system; the one serious failure skewed the SKS cryoplant result. If that one serious failure was removed from the SKS data, the two data sets would have agreed well. It is interesting to note from the failure rate data that the "early life" period for the SKS cryogenic system was shown to be less than 5,000 operating hours-less than 1 year-after a total operation of 22,539 hours in 11 years.

\section{Y. Doi, 1996, "Reliability of Helium Refrigeration Systems for the TRISTAN Detector Magnets," Proceedings of the $16^{\text {th }}$ International Cryogenic Engineering Conference/International Cryogenic Materials Conference, May 20-24, pp. 165-168.}

The TRISTAN machine is an electron-positron accelerator that operated at the KEK laboratory in Tsukuba, Japan. There are three large superconducting magnets on TRISTAN and three helium cryoplants of 300 to $500 \mathrm{~W}$ liquid helium cooling, one per magnet. Each system operated between 42,000 and 49,000 hours. These cryoplants had 169 failure events over 10 years from March 1985 to May 1995. From the repair records, the mean repair rate for these cryosystems was $0.14 / \mathrm{hr}$ and so the average repair time was 7.1 hours. The mean time to repair was stated to include the time for thorough examination of the causes of failure, time for executing remedial measures, and restoration of system operation. By our definition, the cryoplant MTTR given here is really closer to a mean down time, it is just not clear if the author added the time from system problem manifestation to the troubleshooting time that was mentioned. The TRISTAN cryoplants showed an early lifetime of nearly 5,000 hours, which is in agreement with the SKS cryoplant discussion above.

\section{R. E. Barlow and T. Y. Liang, 1977, Availability Analysis of the SUPERHILAC Accelerator, ORC-77-21, accession number ADA047742, July.}

This report gives some system-level MTTR values in hours (see Table 15). These are based on accelerator operations experience.

Table 15. System-level repair times based on accelerator operations (Barlow and Liang 1977)

\begin{tabular}{|l|c|}
\hline \multicolumn{1}{|c|}{ System } & $\begin{array}{c}\text { MTTR } \\
\text { (hr) }\end{array}$ \\
\hline Injector & 5.15 \\
\hline Radio frequency & 1.76 \\
\hline Magnet power supplies & 2.17 \\
\hline Cooling water & 1.0 \\
\hline
\end{tabular}




\begin{tabular}{|l|l|}
\hline Vacuum system & 3.18 \\
\hline Mechanical systems & 1.38 \\
\hline Computer hardware & 2.15 \\
\hline Analog/digital hardware & 1.0 \\
\hline Instrumentation & 6.0 \\
\hline Building power & 2.38 \\
\hline
\end{tabular}




\section{Specialty Facility Data}

This chapter presents some published repair data on facilities that operate with more aggressive technology than light water reactors. These facilities may operate similar to future fusion facilities. Included here are some data from a tritium facility, liquid metal-cooled fission reactor facilities, and gascooled fission reactor facilities. Some repair data on hot cells is also presented.

\section{W. H. Hedley, F. S. Adams and J. E. Wells, 1990, Human Factors Engineering for the TERF Project, MLM-3671, EG\&G Mound Applied Technologies, Miamisburg, Ohio, December.}

Appendix B of this report gives average repair times for tritium gas handling equipment in a system that scavenges tritium from waste gases to be stacked. The system used secondary confinement, primarily gloveboxes and double-walled piping. The components discussed here tend to be small components, more the instrumentation size rather than process size components. For example, millimeter-diameter gas piping, hand-operated small valves (e.g., valves such as Swagelok or Nupro or similar valves of $6.35 \mathrm{~mm}$ opening diameter), cajon fittings, compressors of $<100 \mathrm{~L} / \mathrm{s}$ flow rates, and other small size equipment typically used in tritium facilities. It is noted that some of these times are very modest, so an assumption has been made that these short times for repair of components inside gloveboxes are the expedient repairs that are easily done via gloves and not a repair where extra ventilation is set up and the glovebox window is removed to allow personnel to work inside the glovebox for component replacement or refurbishment. For example, 0.5 hour to repair a valve leak could be the time for the technician to determine which valve in the glovebox is leaking and shut the valve or backseat the valve to stop the leak; the 0.5 hour is a very short time to install a new valve stem seal or to replace the valve. The repair times in this report are described as including detection, notification, the actual repair, and post-repair test. Table 16 is a representative set of the data presented in this report. 
Table 16. Repair times for tritium handling equipment (Hedley et al. 1990)

\begin{tabular}{|l|c|l|}
\hline \multicolumn{1}{|c|}{ Component Description } & $\begin{array}{c}\text { Repair Time } \\
\text { (hr) }\end{array}$ & Notes \\
\hline Manual valve leak & 0.5 & \\
\hline Manual valve blocked (plugged) & 1.0 & \\
\hline Automatic valve leak & 0.5 & \\
\hline Automatic valve blocked (plugged) & 1.0 & 0.8 to $3 \mathrm{~m}^{3} /$ minute flow rate \\
\hline Main Piston compressor fails & 1120.0 & \\
\hline Main Piston compressor minor failure & 1.0 & 0.5 to $1.7 \mathrm{~m}^{3} /$ minute flow rate \\
\hline Compressor circuit breaker trip & 0.5 & \\
\hline Small piston compressor fails & 1120.0 & \\
\hline Small compressor circuit breaker trip & 0.5 & \\
\hline Gas dryer fails & 40.0 & \\
\hline Gas dryer minor failure & 1.0 & \\
\hline Mist eliminator for compressor blocked & 8.0 & \\
\hline Gas preheater leak & 48.0 & \\
\hline Heat exchanger leak & 48.0 & \\
\hline Gas cooler leak & 48.0 & \\
\hline Gas cooler failure & 48.0 & \\
\hline Gas blower leak & 48.0 & \\
\hline Gas blower failure & 48.0 & \\
\hline Water knock-out tank leak & 48.0 & \\
\hline Condenser failure & 48.0 & \\
\hline Preheater failure & 48.0 & \\
\hline Gas filter leak & 1.0 & \\
\hline Gas filter blocked & 1.0 & \\
\hline & & \\
\hline
\end{tabular}

\section{A. J. Arul et al., 2006, "Reliability Analysis of Safety Grade Decay Heat Removal System of Indian Prototype Fast Breeder Reactor," Annals of Nuclear Energy, 33, pp. 180-188.}

There are a few MTTR repair times given for a passive sodium-coolant heat removal system:

- $\quad$ Expansion tank leak $=15$ days

- $\quad$ Piping leak $=15$ days

- Auxiliary heat exchanger leak $=15$ days

- Duplex tube heat exchanger tube leak $=30$ days

- $\quad$ Pneumatic dump valve leak $=3$ days

- Pneumatic dump valve spurious opening $=4$ hours

- Manual isolation valve leak $=4$ hours.

These values refer to 24-hour days as calendar time. The authors did not discuss where these values originated. These values do serve to illustrate the extra time needed when sodium is the coolant.

M. L. Grygiel and C. G. McCargar, 1986, "The Replacement of an Electromagnetic Primary Sodium Sampling Pump in the Fast Flux Test Facility," Proceedings of the International Meeting on Nuclear Power Plant Maintenance, Salt Lake City, Utah, March 23-27, pp. 2-56 to 2-67.

The Fast Flux Test Facility used two electromagnetic pumps for sodium makeup to the primary coolant system. Each pump could attain a maximum flow of $0.006 \mathrm{e} \mathrm{m}^{3} / \mathrm{s}(100 \mathrm{gal} / \mathrm{min})$ at $204^{\circ} \mathrm{C}\left(400^{\circ} \mathrm{F}\right)$. 
One of the pumps suffered cavitation erosion of the pump wall and subsequent leakage to the room. The cavitation occurred because of the pump flow path being deformed. The deformation was caused by sodium expansion during pump meltout. The leaking sodium had failed the terminals for the heat tracing elements. The leak was discovered during a regular plant shutdown; personnel were investigating the apparent heat tracing element failure. The pump was replaced in 33 days. The work was quickly planned after the leak was discovered and crews began on cleanup of the sodium spill, which had created a radiation contact reading of $4.5 \mathrm{mSv} / \mathrm{hr}(450 \mathrm{mrem} / \mathrm{hr})$ and an area reading of $1 \mathrm{mSv} / \mathrm{hr}(100 \mathrm{mrem} / \mathrm{hr})$ near the leaking pump. The source of radiation was primarily Na-22 (half-life 2.6 years, positron emitter) in the spill mass in the frozen sodium in the piping and within other components in the cell. The leak volume was determined to be $0.28 \mathrm{~m}^{3}$ (75 gal), which is $259 \mathrm{~kg}(571 \mathrm{lb})$ of sodium. The spill required 10 days for crews to clean the sodium and decontaminate the area. After that, the radiation area reading had decreased to a level of $0.04 \mathrm{mSv} / \mathrm{hr}(4 \mathrm{mrem} / \mathrm{hr})$. Initially, frozen sodium was chipped and scraped from the pump body and the adjacent cell areas. The sodium reacted with atmospheric moisture, forming sodium hydroxide. The environment was caustic because of $\mathrm{NaOH}$ during sodium cleanup, so selfcontained breathing air and full protective clothing were worn. As the work progressed and the sodium was cleaned up, protective clothing requirements were reduced accordingly. Final sodium cleanup was performed with moist swabs and absorbent cloths. Crews worked around the clock on this task to minimize plant downtime. The pump weighed $636 \mathrm{~kg}$, and there was no crane access in that area of the cell. A metal rail skid track was put in place to move the old pump out and the new pump in to the cell room. After the damaged pump was moved out of its position in the cell, final cleanup was performed of the area. The damaged pump was removed from the room and the new pump was moved in to place and welded to the piping system. The pump was tested and the plant was returned to power. The crews received a collective dose of 45 person-mSv (4.5 person-rem) for this 37-day activity. A chronology is given below in Table 17.

Table 17. Chronology of events to replace an electromagnetic primary sodium sampling pump (Grygiel and McCargar 1986)

\begin{tabular}{|l|l|}
\hline \multicolumn{1}{|c|}{ Event } & \multicolumn{1}{c|}{ Dates } \\
\hline Sodium leak discovered by a crew investigating a failed heating element & November 16, 1984 \\
\hline Repair team is formed, plans begin for replacement of the pump & November 17,1984 \\
\hline Sodium cleanup and decontamination begins & November 19, 1984 \\
\hline Leaking pump is removed from its position in the cell & November 24-26, 1984 \\
\hline Final cell cleanup and decontamination completed & November 29, 1984 \\
\hline Skid track completed for pump removal from the area & November 26-30, 1984 \\
\hline Moved damaged pump out, staged replacement pump & December 1-7, 1984 \\
\hline Moved replacement pump into position & December 8, 1984 \\
\hline Welded replacement pump to piping system & December 10-11, 1984 \\
\hline Pump electrical power and heat tracing reconnected & December 12-19,1984 \\
\hline Newly designed leak detectors installed & December 14, 1984 \\
\hline Sodium meltout of new pump, testing & December 19-20,1984 \\
\hline Cell is closed and re-inerted with nitrogen & December 22, 1984 \\
\hline
\end{tabular}

\section{G. W. Hannaman, 1978, GCR Reliability Data Bank Status Report, GA-A14839, General Atomic Company, July.}

This report gives assessed experience values for typical, average repair times in hours and the lower $5 \%$ and upper $95 \%$ range of repair times. The repair time was defined as the time required to restore a system or component to normal operating status (replacement, in-situ repair, or bypass of the failed part while retaining acceptable system performance). Due to the wide range of repair possibilities and unknowns such as spare parts inventory, ease of maintenance, repair crew availability, etc., these repair 
times have a wide range and are only given for generic equipment. Data were taken from the Peach Bottom helium cooled fission reactor, some experience from carbon dioxide cooled fission reactors, and the water-cooled nuclear fission industry to apply to future helium-cooled fission reactors. A number of components are treated: gas circulators, valves, heat exchangers, auxiliary boiler systems, tanks and vessels, piping per section [a section is assumed to be 10 to 100 feet in length], electrical motors, transformers, circuit breakers, batteries, instrumentation, cables and signal wires, diesel generators, a service water loop, and an instrument air loop. This report supported the probabilistic risk assessment of the South African pebble bed helium-cooled fission reactor design in the 2000 s, so the data remain as useful and valid information.

\section{Bittermann and J. Wehling, 1977, "Reliability Analysis of the Decay Heat Removal System of a 1000-MW(e) Gas-Cooled Fast Breeder Reactor," Nuclear Technology, 32, pp. 247-256.}

This article gives some MTTR active repair times and inspection times. The decay heat system is a gas system, and the circulators are driven by steam turbines.

Table 18. Reliability data for a gas-cooled fast breeder reactor (Bittermann and Wehling 1977)

\begin{tabular}{|l|c|l|}
\hline \multicolumn{1}{|c|}{ Component } & \multicolumn{1}{|c|}{$\begin{array}{c}\text { MTTR } \\
\text { (hr) }\end{array}$} & \multicolumn{1}{|c|}{$\begin{array}{c}\text { Inspection Time Interval } \\
\text { (hr) }\end{array}$} \\
\hline Circulator & 350 & - \\
\hline Circulator drive turbine & 350 & - \\
\hline Turbine control valve & 50 & 3000 almost semi-annually \\
\hline Control valves & 20 & $700 \approx$ monthly \\
\hline Valves (general) & 20 & 700 \\
\hline Steam generator & 350 & - \\
\hline Check valves, main loop & 350 & $8000 \approx$ annually \\
\hline Check valves (water/steam) & 20 & 700 \\
\hline Pumps & 30 & 700 \\
\hline Motors & 30 & 700 \\
\hline Auxiliary steam boiler & 50 & 700 \\
\hline Auxiliary condenser & 50 & 700 \\
\hline Switching signals & 20 & 700 \\
\hline
\end{tabular}

C. E. Stevenson, 1987, The EBR-II Fuel Cycle Story, American Nuclear Society, La Grange Park, Illinois.

This book gives some data from 1965-1968 on the availability of in-cell electro-mechanical (EM) manipulators and in-cell cranes for air atmosphere and argon atmosphere hot cells at Argonne National Laboratory-West. The EM manipulators are carriage mounted with electric motors to move on tracks in the hot cell; they lift up to 340-kg (750lb) loads via lifting hooks. The cranes are also electric motor driven units, rated at 4.5 tonne ( 5 ton) capacity. The data table is reproduced below in Table 19. 
Table 19. Reliability data of in-cell electro-mechanical manipulators and in-cell cranes (Stevenson 1987)

\begin{tabular}{|l|l|c|c|c|c|}
\hline $\begin{array}{c}\text { Equipment Number } \\
\text { and Type }\end{array}$ & $\begin{array}{c}\text { Cell } \\
\text { Type }\end{array}$ & $\begin{array}{c}\text { Count of } \\
\text { Working Days } \\
\text { Equipment } \\
\text { was Available } \\
\text { to be Used }\end{array}$ & $\begin{array}{c}\text { Percent of } \\
\text { Working Days } \\
\text { Equipment } \\
\text { was Available } \\
\text { for Use }\end{array}$ & $\begin{array}{c}\text { Count of } \\
\text { Days } \\
\text { Equipment } \\
\text { was Actually } \\
\text { in Use }\end{array}$ & $\begin{array}{c}\text { Percent } \\
\text { Availability } \\
\text { (days in use } \div \\
\text { days available) }\end{array}$ \\
\hline EM manipulator M-1 & Argon & 464 & 57.3 & 450 & 97.0 \\
\hline EM manipulator M-2 & Argon & 761 & 94.0 & 758 & 99.6 \\
\hline EM manipulator M-3 & Argon & 751 & 92.7 & 718 & 95.6 \\
\hline EM manipulator M-4 & Argon & 770 & 95.1 & 758 & 98.4 \\
\hline EM manipulator M-5 & Argon & 554 & 68.4 & 545 & 98.4 \\
\hline EM manipulator M-6 & Argon & 728 & 89.9 & 708 & 97.2 \\
\hline $\begin{array}{l}\text { EM manipulator } \\
\text { average value }\end{array}$ & Argon & 671 & 82.9 & 656 & 97.7 \\
\hline EM manipulator M-7 & Air & 807 & 99.6 & 807 & 100.0 \\
\hline EM manipulator M-8 & Air & 808 & 99.8 & 806 & 99.8 \\
\hline $\begin{array}{l}\text { EM manipulator } \\
\text { average value }\end{array}$ & Air & 808 & 99.7 & 807 & 99.9 \\
\hline In-cell crane C-1 & Argon & 810 & 100.0 & 406 & 50.1 \\
\hline In-cell crane C-2 & Argon & 777 & 95.9 & 583 & 75.0 \\
\hline $\begin{array}{l}\text { In-cell crane } \\
\text { average value }\end{array}$ & Argon & 794 & 98.0 & 495 & 62.6 \\
\hline In-cell crane C-3 & Air & 790 & 97.5 & 782 & 99.0 \\
\hline
\end{tabular}

E. Opare, 2011, "Strategizing Enterprise System Upgrades Using RAM Simulation," INL/JOU-1121473, March, this article has not reached publication.

In this paper, hot cell master/slave manipulator repair times were estimated from expert input given by hot cell engineers at the INL. The master arm, the through-shielding-wall seal tube, and the slave arm were each estimated to require 168 clock hours to repair, regardless of the hot cell atmosphere. The number of personnel was not given, but there would be at least two workers for a buddy system and likely more workers needed. 


\title{
5. Commercial and Industrial Data
}

\author{
Det Norske Veritas, 2009, Offshore Reliability Data, $5^{\text {th }}$ edition, Volume 1 -Topside Equipment, Det \\ Norske Veritas, Hovick, Norway.
}

This is a very good data compilation for failure rates and repair times for oil drilling platform and rig equipment operating in salt water environments. Most of the entries have repair times by failure mode and the repair data are the active repair hours, mean and maximum, and the man-hours, mean and maximum. The dataset includes machinery such as compressors, gas turbines, pumps, combustion engines, and turbo expanders. There is also electric equipment, including electric generators and motors. Heat exchangers, vessels, and heaters/boilers are also addressed. Some control and safety equipment is included: fire and gas detectors, process sensors, control logic units, and control valves. This is an excellent data set, but its use must be tempered by the unique industry and environment considerations of the oil rigs where these data originate.

\section{IEEE, 2007, IEEE Recommended Practice for the Design of Reliable Industrial and Commercial Power Systems, IEEE Std 493-2007, New York, Chapter 10.}

This standard gives an overview of reliability surveys that have been conducted at commercial and industrial facilities. Part of the survey data included repair times. The industry average of actual hours of downtime per failure are given for transformers, motors, a variety of circuit breakers, motor starters, generators, switches, bus ducts, cables, cable joints, and cable terminations and are based on the survey data. The dataset from Hale and Arno (described below) are repeated in this standard. Even some older data from 1974 are given (the "Report on Reliability Survey of Industrial Plants, Parts I-VI" in IEEE Transactions on Industry Applications, 1974). That survey has been a widely used study for many years and it is reported in this standard.

M. A. Hawks, 2006, Maintenance Practices for Emergency Diesel Generator Engines onboard United States Navy Los Angeles Class Nuclear Submarines, Master's thesis, Massachusetts Institute of Technology, June. Available at http://www.dtic.mil/dtic/search/tr/tr.html.

This thesis examines maintenance records from 1989 to 2005 for 62 submarines. The submarine diesel engine is smaller (that is, probably less than $300 \mathrm{~kW}$ electric) than power plant diesel generators (Lobner et al. 1990) at 1.5 to $2.5 \mathrm{MW}$ electric. The nature of a naval submarine must be understood to interpret these data. The submarine goes to drydock perhaps every 1.5 or 2 years and the diesel engine is totally overhauled for inspection and refurbishment. This activity cannot be carried out while at sea. Therefore, the times listed here are not unusual for complete maintenance overhaul of engine teardown and rebuild. The data in this thesis show that for these engines the MTTR an engine was 87 days, with a best value of 21 days and a worst value of 203 days.

\section{H. Procaccia, S. P. Arsenis, P. Aufort, 1998, European Industry Reliability Data Bank, EIReDA, Crete University Press.}

This book has a wide body of data on mechanical components (accumulators, compressors, orifice meters, filters, heat exchangers, pumps, tanks, turbines, and valves), electrical components (batteries, circuit breakers, motors, generators/engines, inverters, power supplies, transmission lines, relays, and transformers), and instrumentation \& control (reactor protection systems, command/control systems, regulation sets, sensors, and transducers). There is also a set of generic data given at the end of the book. The book gives mean active repair times in MTTR hours and in man-hours for most of the entries. The analyst is cautioned that these data arise from a mixture of nuclear (e.g., Electricity de France) and non- 
nuclear industrial use so the data do not necessarily reflect any precautions taken for radiological protection. This is a good data set arising from plants that kept records of the work performed.

M. J. Cullinane, 1989, "Determining Availability and Reliability for Water Distribution Systems," in Reliability Analysis of Water Distribution Systems, L. W. Mays, editor, American Society of Civil Engineers, New York, Chapter 7.

This chapter gives data on CM, PM, and MTTR for a variety of water distribution equipment, including pumps, valves, motors, controls, and pipes. A few data points are given in Table 20 .

Table 20. Typical repair data for water distribution components (Cullinane 1989)

\begin{tabular}{|c|c|c|}
\hline Component & $\begin{array}{c}\text { MTTR } \\
\text { (hr) }\end{array}$ & $\begin{array}{c}\text { PM } \\
\text { (hr/yr) }\end{array}$ \\
\hline Pump & 9.6 & 2 \\
\hline Power transmission & 2.3 & 7 \\
\hline Motor & 6.9 & 14 \\
\hline Valve & 11.6 & 41 \\
\hline Controls & 3.7 & 9 \\
\hline
\end{tabular}

\section{J. A. Derdiger, K. M. Bhatt, W. E. Siegfriedt, 1981, Component Failure and Repair Data for Coal- Fired Power Units, EPRI AP-2071, Electric Power Research Institute, Palo Alto, California, October.}

This report gives the relative frequency percentage of a failure, the logistic time in hours, the repair time (in clock hours and total man-hours), the train shutdown time, the train startup time, the total restore time, and the mean time to restore contribution (which is the relative frequency/100 multiplied by the total restore time). These data are best estimates from experts in the coal plant industry. The data are well defined and displayed. There are a number of components treated, including air heaters, air separators, ash handling equipment, bag filters, a variety of pumps, conveyors, crushers, condensers, deaerator heaters and storage tanks, flue gas desulfurization equipment, tanks, blowers, industrial vacuum pumps, fans, generators, water heaters, hoppers, agitators, steam turbines, strainers, and vacuum filters.

\section{R. P. Dawkins and J. A. Derdiger, 1982, Component Failure and Repair Data: Gasification- Combined-Cycle Power Generation Units, EPRI-AP-2205, Electric Power Research Institute, Palo Alto, California, February.}

This report is very similar to the Coal-Fired Power Unit report EPRI AP-2071 described above (it gives the same repair data) but there are some different equipment items treated in this report. The data came from experts in the combined-cycle power industry. Some of the equipment includes acid gas knock out drum, ammonia absorber, oxygen coolers, oxygen compressor, oxygen compressor turbine driver, particulate scrubbers, rod mill, scalping screens, slurry tanks, slurry pumps, sulfur condenser, sulfur furnace, sulfur transfer pump, trim cooler, and wet screens.

\section{P. S. Hale, Jr., and R. G. Arno, 2001, "Survey of Reliability and Availability Information for Power Distribution, Power Generation, and HVAC Components for Commercial, Industrial, and Utility Installations," ASHRAE Transactions, 107, pp. 360-389.}

This article gives the results of a 24,000 man-hour U.S. Army Corps of Engineers study of 204 power generation, power distribution, and heating, ventilation and air-conditioning items over $\mathrm{a} \approx 2$ year period. The article addresses a variety of equipment and gives MTTR (CM), MTTM (PM), the MDT, the mean 
time between maintenance, and the mean hours down time per year. The equipment treated includes accumulators, air compressors, air dryers, air handling units, lightning arresters, batteries, blowers, boilers, bus ducts, cabinet heaters, cables, cable connections, capacitor banks, battery chargers, chillers, circuit breakers, refrigerant compressors, condensers, control panels, convectors, cooling towers, dampers, diesel generators, adjustable speed drives, evaporators, filters, fuses, gas turbine generators, level gauges, heat exchangers, inverters, DC motors, motor generator sets, motor starters, piping, pressure control assemblies, pressure regulators, pumps, switches, switchgear, tanks, transducers, transformers, uninterruptible power supplies, valves, valve operators, voltage regulators, and water cooling coils.

\section{P. S. Hale, Jr., R. G. Arno, and S. J. Briggs, 1999, "Operational Maintenance Data for Power Generation, Distribution and HVAC Components," IEEE Transactions on Industry Applications, 35, pp. 282-297.}

These data come from the overall study described the article published in the ASHRAE transactions (the article is discussed above), but there is some discussion about maintenance - that more companies are hiring outside contractors to perform maintenance instead of having permanent staff. The contract companies tend to increase response time for CM. Also, gas turbines have shown reliability growth, they are more reliable than in the 1970 s, so maintenance needs are fewer.

\section{W. Schultz and V. B. Parr, 1982, Evaluation and Documentation of Mechanical Reliability of Conventional Wastewater Treatment Plant Components, EPA-600/2-82-044, accession number PB82-227539, U.S. Environmental Protection Agency, Cincinnati, Ohio, March.}

This report surveyed mechanical equipment records at several wastewater treatment plants to develop reliability and maintainability information. The MTTR, the CM hours per unit per year, and the PM hours per unit per year were given. The PM hours per unit per year were on the order of just a few minutes, which is interpreted to mean a cursory visual inspection for dripping water or stains from evaporated water, leaking lubricant, etc. The equipment surveyed includes a variety of types and sizes of pumps, power transmission equipment (e.g., variable speed drives), motors, compressors, air/water diffusers, valves, controllers, pressure vessels, conveyors, settling clarifiers, and mechanical mixers. The reader should note that while this dataset is $\approx 30$ years old, it is still being cited in recent texts (Tung et al. 2006). This report does give some PM times as well as CM times. It should be clear to the reader that the legal requirements for wastewater treatment plant PM are not demanding because these PM times vary from 0.3 minutes to 1.6 minutes per year. That amount of time is basically a brief visual inspection. However, it should be noted that even a brief inspection can be revealing - the craftsman will note unusual sounds coming from vibration of degraded bearings, stains from dried coolant if there has been leakage in the vicinity, etc. Some representative values are given below in Table 21.

Table 21. Reliability of conventional wastewater treatment plant components (Schultz and Parr 1982)

\begin{tabular}{|l|c|c|c|c|}
\hline \multicolumn{1}{|c|}{$\begin{array}{c}\text { Multiphase Electric Motor Size } \\
\text { (hp) }\end{array}$} & $\begin{array}{c}\text { MTBF } \\
\text { (hr) }\end{array}$ & $\begin{array}{c}\text { PM } \\
\text { (hr/yr) }\end{array}$ & $\begin{array}{c}\text { CM } \\
\text { (hr/yr) }\end{array}$ & $\begin{array}{c}\text { MTTR } \\
\text { (hr) }\end{array}$ \\
\hline 0 to 1 & 214,700 & 0.00522 & 0.01009 & 2.6 \\
\hline 1 to 5 & 564,600 & 0.01152 & 0.0 & - \\
\hline 6 to 25 & 62,100 & 0.00015 & 0.03261 & 7.857 \\
\hline 26 to 100 & 46,000 & 0.00108 & 0.03098 & 4.96651 \\
\hline 101 to 500 & 54,000 & 0.00328 & 0.10599 & 12.05617 \\
\hline$>500$ & 23,100 & 0.02683 & 0.24917 & 8.433 \\
\hline
\end{tabular}




\section{K. DeFord, 1999, Saltwell Pumping Systems RAM Analysis, RPP-5129, Rev. 0, Lockheed Martin Hanford Company, October.}

This report describes jet pumps used to draw out the liquid from sludge and saltcakes in single wall tanks that were used to store liquid radioactive waste at the Hanford site. The liquid is put into double walled tanks for interim storage before processing. There are no component level repair times, but there are some interesting PM data. During water transfer operations, the jet pump must be shut down once per week and the transfer lines flushed to prevent solids precipitation from plugging the lines. The flush PM requires 8 hours per week. In addition, the pumping control system routine PM, including calibration, requires 160 hours/year. The underground transfer lines are required to be re-validated by a hydro test every 12 months. This requires a one-week shutdown on average for the lines routed to a single tank. The author did not describe why a hydro test required one week. Presumably, this time is needed for orderly shutdown of operations, draining the line, decontaminating the line as much as possible, closing off the ends of the line, bringing a test pump and water source to the location, pumping with water for the hydrotest that only requires perhaps an hour, then re-opening and returning the transfer lines to service.

\section{Butler, 2000, Guide to Ship Repair Estimates (in man-hours), Butterworth Heinemann, Amsterdam.}

This book is based on the author's long experience in ship refitting so the data represent actual times for the tasks that are addressed. While the focus of this book is on small- and medium-sized ships, the data can be used for estimates to land-based equipment as well. Given that ships tend to have a small floor space and congested work conditions, these data may be highly applicable to some power plant equipment that has poor access or crowded conditions. There are sections on the man-hours per tonne for weld removal of hull plating and installation of new hull plating, pipework removal and replacement in man-hours per meter of steel pipe, diesel engine overhaul in man-hours per cylinder, condenser cleaning by air or water lance in man-hours based on the size of the compressor, pump overhaul in man-hours based on pump capacity, and electrical generator refurbishment in man-hours based on generator kVA. There are no repair distributions but these are reasonable repair times for the equipment listed above.

\section{P. S. Hale, Jr., and R. G. Arno, 1999, "Survey of Reliability Information on Lead Acid Batteries for Commercial, Industrial, and Utility Installations," Proceedings of the Industrial and Power Systems Technical Conference, Sparks, Nevada, May 2-6.}

This paper gives maintenance time information for two types of storage batteries. The results are in Table 22 below. The lead acid battery has more lengthy maintenance actions than the sealed battery. The gel cell batteries operate in the same manner as lead acid batteries, but a self-contained gel replaces the sulfuric acid liquid solution that is used in the lead acid battery. The data in the table show that the mean time between failures is much longer for the lead acid battery but its repair time is also longer. Neither battery had any mean time to maintain reported, although lead acid batteries have periodic checks of the liquid solution and hydrogen outgassing into battery rooms.

Table 22. Battery summary information (Hale and Arno 1999)

\begin{tabular}{|l|c|c|c|}
\hline $\begin{array}{c}\text { Type of Energy Storage } \\
\text { Battery }\end{array}$ & $\begin{array}{c}\text { MTTR } \\
\text { (hr) }\end{array}$ & $\begin{array}{c}\text { MTTM } \\
\text { (hr) }\end{array}$ & $\begin{array}{c}\text { MTBF } \\
\text { (hr) }\end{array}$ \\
\hline Gel Cell-Sealed Battery & 2 & 0 & $434,961.38$ \\
\hline Lead Acid Battery & 32.13 & 0 & $1,173,590.33$ \\
\hline
\end{tabular}




\section{R. M. Fricks, K. S. Trivedi, 1998, “Availability Modeling of Energy Management Systems,"}

Microelectronics Reliability, 38, pp. 727-743.

This paper gives some suggested data on typical MTTRs for computing equipment. These data are older but could be used in a preliminary assessment. A table of values is given below in Table 23 .

Table 23. Repair times for computing equipment (Fricks and Trivedi 1998)

\begin{tabular}{|l|c|c|}
\hline \multicolumn{1}{|c|}{ Component Description } & $\begin{array}{c}\text { Mean Time to Failure } \\
\text { (hr) }\end{array}$ & $\begin{array}{c}\text { MTTR } \\
\text { (hr) }\end{array}$ \\
\hline Data acquisition computer & 8760 & 3 \\
\hline File server & 8760 & 12 \\
\hline Disk controller & 8760 & 6 \\
\hline Disk unit & 8760 & 24 \\
\hline High-end workstation & 4380 & 6 \\
\hline Low-end workstation & 4380 & 6 \\
\hline X-terminal & 8760 & 3 \\
\hline Communications workstation & 4380 & 6 \\
\hline
\end{tabular}

\section{Smith, M. Donovan, M. Bartos, 1990, "Reliability Survey of 600- to 1800-kW Diesel and Gas-} Turbine Generating Units," IEEE Transactions on Industry Applications, 26, pp. 741-755.

This article reports the results of a survey taken of commercial and military facilities for the RAM of generators producing less than 2 MW electricity. The results are given in Table 24 .

Table 24. Diesel generator and gas turbine maintainability values (Smith et al. 1990)

\begin{tabular}{|l|c|c|c|c|c|c|}
\hline \multirow{2}{*}{ Measure } & \multicolumn{2}{|c|}{$\begin{array}{c}\text { Diesel Generator with } \\
\text { Auxiliary Systems } \\
\text { (hr) }\end{array}$} & $\begin{array}{c}\text { Package Unit Diesel } \\
\text { Generator } \\
\text { (hr) }\end{array}$ & \multicolumn{2}{c|}{$\begin{array}{c}\text { Gas Turbine } \\
\text { (hr) }\end{array}$} \\
\cline { 2 - 7 } & Continuous & Standby & Continuous & Standby & Continuous & Standby \\
\hline MTTR & 2.9 & 2.8 & 6.4 & 3.9 & 7.2 & 111.6 \\
\hline MTTM & 1.3 & 3.8 & 12.5 & 7.8 & 21.1 & 10.6 \\
\hline MDT & 1.7 & 3.5 & 9.9 & 6.5 & 14.8 & 36.1 \\
\hline MTTCM & 2.8 & 2.9 & 4.3 & 2.9 & 5.7 & 77.4 \\
\hline Note: MTTCM is mean time to perform CM, in clock hours \\
\hline
\end{tabular}

\section{R. E. Wright and M. B. Sattison, 1987, A RAM Analysis of the Proposed Tinker AFB Jet Fuel Storage Tank Facility, EGG-REQ-7807, Idaho National Engineering Laboratory, August.}

The authors of this report interviewed air base maintenance personnel and, from the results of those interviews, developed repair time estimates for a variety of equipment. The time estimates are clock hours of repair time from detection of component failure to the component being returned to service, which is the down time for the component. The authors used the lognormal distribution to characterize the repair time process. The data apply to jet fuel pumping systems that draw from large storage tanks $\left(6,435 \mathrm{~m}^{3}\right.$ or 1.7 million gallon tanks), flowing fuel to refueling trucks (e.g., 11 to $38 \mathrm{~m}^{3}$ or 3,000 to 10,000 gallon capacity refueler trucks). Fuel flow rates are considered to be on the order of $380 \mathrm{~L} / \mathrm{min}$ (100 gal/min) into and out of the aircraft refueler trucks. There are also components from aqueous film forming foam (flow rate on the order of $1,900 \mathrm{~L} / \mathrm{min}$ or $500 \mathrm{gal} / \mathrm{min}$ ) and water fire protection systems. The data are reproduced in Table 25. 
Table 25. Repair time database for jet fuel and airport fire equipment active repair times (Wright and Sattison 1987)

\begin{tabular}{|c|c|c|c|}
\hline Component & $\begin{array}{c}\text { Median } \\
\text { Repair Time } \\
\text { (hr) }\end{array}$ & $\begin{array}{l}\text { 95\% Upper Bound } \\
\text { Time } \\
\text { (hr) }\end{array}$ & $\begin{array}{c}5 \% \text { Lower } \\
\text { Bound Time } \\
\text { (hr) }\end{array}$ \\
\hline Diesel pump & 8.0 & 72.0 & 0.5 \\
\hline Motor pump & 10.0 & 20.0 & 6.0 \\
\hline Flow control valve & 4.0 & 12.0 & 1.0 \\
\hline Level control valve & 5.0 & 8.0 & 1.0 \\
\hline Emergency valve & 4.0 & 8.0 & 2.0 \\
\hline Gate valve & 1.0 & 2.0 & 0.5 \\
\hline Butterfly valve & 4.0 & 8.0 & 2.0 \\
\hline Ball valve & 2.0 & 6.0 & 0.5 \\
\hline Check valve & 2.0 & 4.0 & 1.0 \\
\hline Backflow preventer & 4.0 & 8.0 & 0.5 \\
\hline Double block valve & 1.5 & 4.0 & 0.5 \\
\hline Safety valve & 3.0 & 4.0 & 2.0 \\
\hline Y strainer & 0.5 & 2.0 & 0.25 \\
\hline Screen mesh filter & 0.5 & 2.0 & 0.25 \\
\hline Filter separator & 5.0 & 8.0 & 2.0 \\
\hline Foam proportioner & 4.0 & 8.0 & 2.0 \\
\hline Foam maker & 4.0 & 8.0 & 2.0 \\
\hline Foam orifice & 1.5 & 2.0 & 1.0 \\
\hline Air eliminator & 1.5 & 3.0 & 1.0 \\
\hline Pole transformer & 3.0 & 5.0 & 2.5 \\
\hline Isolation switch & 0.75 & 4.0 & 0.5 \\
\hline Breaker & 0.75 & 1.0 & 0.5 \\
\hline Fuse & 0.75 & 1.0 & 0.5 \\
\hline Bus & 4.0 & 6.0 & 2.0 \\
\hline Cable & 2.5 & 4.0 & 1.0 \\
\hline Contactor & 1.0 & 1.5 & 0.5 \\
\hline Pipe & 4.0 & 8.0 & 2.0 \\
\hline Flow indicator & 1.0 & 2.0 & 0.5 \\
\hline Tank & 0.03 & 0.1 & 0.01 \\
\hline Flow element & 1.5 & 4.5 & 0.5 \\
\hline Human error & 0.1 & 0.2 & 0.05 \\
\hline
\end{tabular}

A. Norris, 1989, "Report of the Circuit Breaker Reliability Survey of Industrial and Commercial Installations," Proceedings of the Industrial and Commercial Power Systems Technical Conference, Chicago, Illinois, May 7-11, pp. 1-16.

This article gives the results of a survey of commercial and industrial firms. Circuit breakers of varying types are discussed. Some data are given in Table 26.

Table 26. Repair times for various circuit breakers (Norris 1989)

\begin{tabular}{|l|c|c|c|c|}
\hline & \multicolumn{4}{|c|}{$\begin{array}{c}\text { Failure Duration } \\
\text { (hr/failure) }\end{array}$} \\
\hline \multicolumn{1}{|c|}{ Circuit breaker description } & Minimum & Average & Median & Maximum \\
\hline $0-600$ V air magnetic & 0.5 & 2.8 & 4 & 4 \\
\hline $601-15,000$ Vair magnetic & 1 & 2.25 & 2 & 4 \\
\hline $34.5-138$ kV bulk oil & 1 & 41.11 & 3 & 240 \\
\hline
\end{tabular}




\section{P. O'Donnell, 1985, "Report of Large Motor Reliability Survey of Industrial and Commercial Installations, Part I," IEEE Transactions on Industry Applications, 21, pp. 853-864.}

This article gives some down times by motor size for induction and synchronous motors. Some of the data are shown in Table 27.

Table 27. Summary information for large motors (O’Donnell 1985)

\begin{tabular}{|l|c|c|}
\hline \multicolumn{1}{|c|}{ Equipment Class } & $\begin{array}{c}\text { Mean Down Time per Failure } \\
\text { (hr) }\end{array}$ & $\begin{array}{c}\text { Median Down Time per Failure } \\
\text { (hr) }\end{array}$ \\
\hline $0-1000$ V induction & 42.5 & 12.0 \\
\hline $1001-5000$ V induction & 75.1 & 12.0 \\
\hline $1001-5000$ V synchronous & 78.9 & 16.0 \\
\hline
\end{tabular}

\section{Chrysler Corp Warren, MI Missile Division, 1964, Analysis of Maintenance Task Time Data, Covering Electrical, Electronic and Electro-mechanical Components during Weapon System Operational Phase, RADC-TR-64-373, Volume 1, Rome Air Development Center.}

This report has tables listing the minimum, average, and maximum maintenance man-hours for repairing and replacing components. There are over a hundred components, including electrical connectors, headsets, immersion heaters, lamps, meters, motors, solenoid valves, switches, capacitors, relays, resistors, magnetic tape, thermocouples, transformers, and cryogenic vent valves. The data are also provided by major item, such as mobile diesel generator, liquid nitrogen and liquid oxygen trailers, cryogenic generating plant, fuel transporter, and rocket engine test stand.

\section{Hrivnak, 1989, "Breakdown and Repair of Large Spherical Containers for Liquefied Hydrocarbon Gases," International Journal of Pressure Vessels and Piping, 40, pp. 193-222.}

This paper describes that a facility using twelve tanks of 1,500 to $3,300 \mathrm{~m}^{3}$ volume to store liquefied propane, propylene, ethylene, and other gases began to experience macroscopic cracks in welds. The cracks were caused by hydrogen-induced cracking during the manual metal arc welding used in tank construction. The time to complete repairs on one of the $3300 \mathrm{~m}^{3}$ tanks was nearly 5 months with a crew of 20 welders and 30 workmen. About 340 meters of welds had to be fabricated, which required about 12 tons of welding electrode. The original weld was removed by graphite electrode gouging (with preheating the tank wall to $80^{\circ} \mathrm{C}$ ), the weld metal edges were then ground and etched at $50^{\circ} \mathrm{C}$ with a $30 \%$ aqueous solution of nitric acid, followed with inspection by dye penetrant. Then the weld could be remade. After the weld repairs, full non-destructive testing was performed using both ultrasonic inspection and magnetic particle testing with the tank empty. After that inspection, the tank was pressurized to redistribute the stresses in two pressurization cycles while tension measurements were taken and acoustic emissions were monitored. The tank was then pressurized to its maximum pressure of $2.85 \mathrm{MPa}$ and the weld inspection was repeated. The tank was re-certified for service with an expected 15 -year lifetime. The author did not state the welding time and the inspection time in the 5 months of repairs. However, as a major repair activity, these data are indicative of the time required for craftsmen to perform the weld repair task, re-positioning themselves around a large tank repeatedly for weld removal, weld repair, and inspections. 


\section{A. P. Harris, 1984, Reliability and Maintainability Data for Industrial Plants, TD-84-3, A. P. Harris}

and Associates, Ottawa, Canada.

This report is difficult to find. Below is an excerpt from the report (Table 28).

Table 28. Repair times for industrial plant components (Harris 1984)

\begin{tabular}{|c|c|c|}
\hline Component & Repair Time Range & Median Repair Time \\
\hline $\begin{array}{l}\text { Bellows, metal convolution, stroke to } 7.5 \mathrm{~cm} \text {, } \\
\text { up to } 23 \text { bar }\end{array}$ & 1.0 to $3.0 \mathrm{hr}$ & \\
\hline \multicolumn{3}{|l|}{ Bolts and machine screws } \\
\hline$<9.5 \mathrm{~mm}$ diameter & 6 to $12 \mathrm{~min}$ & \\
\hline 9.5 to $19 \mathrm{~mm}$ diameter & 12 to $24 \mathrm{~min}$ & \\
\hline$>19 \mathrm{~mm}$ diameter & 30 to $76 \mathrm{~min}$ & \\
\hline Cables for electric power & 5.3 to $47.5 \mathrm{hr}$ & \\
\hline $0-600 \mathrm{~V}$ & $10.5 \mathrm{hr}$ & \\
\hline $601-15,000 \mathrm{~V}$ & $6.9 \mathrm{hr}$ & \\
\hline Circuit breakers, all types & 1.0 to $8.0 \mathrm{hr}$ & $4.0 \mathrm{hr}$ \\
\hline $\begin{array}{l}\text { Compressors for air or gas } 0.3 \text { to } 330 \text { bar, } 280 \\
\text { to } 280,000 \mathrm{~L} / \mathrm{min} \text {, excludes motor drive and } \\
\text { auxiliary equipment }\end{array}$ & 4.0 to $79.8 \mathrm{hr}$ & \\
\hline $\begin{array}{l}\text { Ducts, trays, wireways for cables } 0.8 \text { to } 12.9 \\
\text { hr }\end{array}$ & $9.5 \mathrm{hr}$ & \\
\hline $\begin{array}{l}\text { Fans and blowers, motor not included, up to } \\
2800 \mathrm{~m}^{3} / \mathrm{min} \text { and larger }\end{array}$ & 1.47 to $84 / 1 \mathrm{hr}$ & $23.62 \mathrm{hr}$ \\
\hline $\begin{array}{l}\text { Filters, water, for particles } 5 \text { to } 100 \text { microns, } \\
\text { up to } 68 \mathrm{~m}^{3} / \mathrm{hr}\end{array}$ & 13.8 to $52.0 \mathrm{~min}$ & $23.4 \min$ \\
\hline \multicolumn{3}{|l|}{ Gaskets and seals } \\
\hline o-rings & $0.365 \mathrm{hr}$ mean & \\
\hline Sliding seals & $0.305 \mathrm{hr}$ mean & \\
\hline Rotating seals & $0.365 \mathrm{hr}$ mean & \\
\hline Flat gaskets & $0.218 \mathrm{hr}$ mean & \\
\hline Packing & $0.201 \mathrm{hr}$ mean & \\
\hline $\begin{array}{l}\text { Instrumentation for liquid flow, level, pressure, } \\
\text { or temperature }\end{array}$ & 0.25 to $24 \mathrm{hr}$ & $6 \mathrm{hr}$ mean \\
\hline Panels, such as $480 \mathrm{~V}$ motor control centers & 6.6 to $34.1 \mathrm{hr}$ & \\
\hline Power supplies, uninterruptible, 1 to $100 \mathrm{kVA}$ & 2.2 to $8.0 \mathrm{hr}$ & $5.0 \mathrm{hr}$ \\
\hline Smoke detectors & 42 to $60 \mathrm{~min}$ & \\
\hline Wire, low power, to $600 \mathrm{~V}$ & 22 to $45 \mathrm{~min}$ & \\
\hline
\end{tabular}

\section{A. T. Upfold, 1971, "Manhour Ratings Standardized for Instrument Maintenance," Instrumentation Technology, 18, February, pp. 46-48.}

This short article gives the results of a survey of 150 instrumentation maintenance experts who were asked for information on man-hour times to repair a wide variety of instruments. Granted, these data are older but they are also comprehensive. Table 29 gives the data. It is noted that these data are repeated in newer texts as well. Some improvements in instrumentation technology have served to reduce the PM time (Hashemian et al. 1993) but these data on older equipment may serve as an upper bound of the times needed for newer electronic instrumentation. 
Table 29. Instrument PM man-hours per year (Upfold 1971)

\begin{tabular}{|c|c|c|c|}
\hline Instrument & $\begin{array}{c}\text { PM Man-hours } \\
\text { Mean } \\
\text { (hr/yr) }\end{array}$ & $\begin{array}{l}\text { Range } \\
\text { (hr/yr) }\end{array}$ & $\begin{array}{c}\text { Standard Deviation } \\
\text { (hr/yr) }\end{array}$ \\
\hline \multicolumn{4}{|l|}{ Pressure transducer } \\
\hline Bourdon tube & 4 & $3-5$ & 0.41 \\
\hline Bellows & 3 & $2-5$ & 0.70 \\
\hline \multicolumn{4}{|l|}{ Flow differential pressure transducer } \\
\hline Diaphragm & 6 & $4-8$ & 0.70 \\
\hline Bellows & 6 & $5-7$ & 0.70 \\
\hline Mercury & 8 & $6-10$ & 0.26 \\
\hline Magnetic flow meter & 8 & $6-10$ & 0.26 \\
\hline Turbine flow meter & 10 & $8-12$ & 0.24 \\
\hline Positive displacement flow meter & 10 & $8-12$ & 0.24 \\
\hline \multicolumn{4}{|l|}{ Level differential pressure transducer } \\
\hline Diaphragm & 5 & $4-7$ & 0.81 \\
\hline Bellows & 4 & $3-6$ & 0.76 \\
\hline Mercury & 5 & $4-6$ & 0.35 \\
\hline Float level instrument & 5 & $4-6$ & 0.35 \\
\hline Capacitance level instrument & 6 & $4-8$ & 0.66 \\
\hline Displacer level instrument & 5 & $4-7$ & 0.66 \\
\hline Radiation level instrument & 10 & $8-12$ & 2.1 \\
\hline Bubble pipe level instrument & 4 & $3-5$ & 0.35 \\
\hline $\begin{array}{l}\text { Force balance temperature fluid bulb } \\
\text { instrument }\end{array}$ & 4 & $3-6$ & 0.46 \\
\hline $\begin{array}{l}\text { Motion balance temperature fluid } \\
\text { bulb instrument }\end{array}$ & 4 & $3-8$ & 0.44 \\
\hline Pressure controller & 5 & $4-7$ & 2.5 \\
\hline Flow controller & 6 & $5-8$ & 0.82 \\
\hline Level controller & 5 & $4-7$ & 2.5 \\
\hline Temperature controller & 5 & $4-7$ & 2.5 \\
\hline $\mathrm{pH}$ analyzer & 29 & $20-40$ & 6.21 \\
\hline Gas chromatograph & 145 & $130-170$ & 2.5 \\
\hline Oxygen analyzer & 38 & $35-42$ & 2.1 \\
\hline CO2 analyzer & 21 & $18-25$ & 2.1 \\
\hline Infrared analyzer & 76 & $62-94$ & 5.69 \\
\hline Boiling point analyzer & 80 & $74-85$ & 4.82 \\
\hline Combustibles analyzer & 50 & $44-61$ & 3.74 \\
\hline Displacement density instrument & 34 & $29-40$ & 3.16 \\
\hline Radiation density instrument & 40 & $33-49$ & 4.0 \\
\hline Control valve, globe & 5 & $4-6$ & 0.41 \\
\hline Control valve, butterfly & 7 & $6-9$ & 0.76 \\
\hline Control valve, Saunders-type & 7 & $6-8$ & 0.70 \\
\hline \multicolumn{4}{|l|}{ Diaphragm valve recorder/indicator } \\
\hline Pressure & 4 & $3-6$ & 0.58 \\
\hline Flow & 6 & $5-8$ & 0.49 \\
\hline Level & 5 & $4-7$ & 0.70 \\
\hline Temperature & 4 & $3-6$ & 0.58 \\
\hline
\end{tabular}

\section{Construction Estimation Data}

The reports described in previous chapters are from actual experiences and are the most likely data to be accurate for repair work in other, similar applications. However, the published data do not address all 
aspects of maintenance. The analyst has other data available to support estimation of component replacement tasks. The data sets in this chapter can be used with the assumption that component removal time $=$ construction installation time. New component installation time $=$ construction installation time. That is, double the construction time to obtain an estimate of the component replacement time. While these assumptions may not be the best assumptions in all situations, they do allow a starting point for an estimate of failed component replacement.

Please note that some of these estimation books give multipliers to account for multiple-craftsmen crowding or congested conditions, for adverse weather, for cramped working conditions (such as a trench or crawlspace), and other factors. There can also be other issues to account for in nuclear facility maintenance; these are discussed in the next section.

\section{J. Gladstone and K. K. Humphreys, 1995, Mechanical Estimating Guidebook, McGraw-Hill Book Company, New York.}

This text gives work-hour estimates to install various types of equipment, including cooling and refrigeration equipment, heating equipment, fans and blowers, cooling towers, pumps, tanks, piping, ductwork, air distribution ducting, thermal insulation, instrumentation and controls, electrical wiring, fire alarm systems, and other equipment. The estimates are given in work-hours, which are more often referred to as man-hours. A crew of two craftsmen is routinely assumed. Thus, if an installation requires 6 work-hours, and there is a crew of two craftsmen, then only 3 clock hours are needed to perform the installation. A number of correction factors are also given, including weather conditions, area conditions (distance from the home base), general conditions (such as overtime), and task conditions (work in confined spaces, on ladder, on scaffold, etc.).

\section{J. S. Page, 1999, Estimator's Electrical Man-hour Manual, third edition, Gulf Publishing Company, Houston, Texas.}

This book gives detailed man-hours for installing a wide variety of electrical equipment, including electrical junction boxes, switch boxes, galvanized rigid steel conduit, aluminum conduit, plastic conduit, cable, wiring, wiring connectors, armored cable up to $15 \mathrm{kV}$, metal raceways and busways, lights, ducts, electric heating and ventilating, panelboards, switchboards, switches, starters, controls, motor control centers, motor controls, motors, transformers, and communication systems.

\section{J. S. Page, 1999, Estimator's Piping Man-Hour Manual, $5^{\text {th }}$ edition, Gulf Professional Publishing, Houston, Texas.}

This book gives detailed man-hours for pipe installation. It includes man-hours by foot of pipe, mainly carbon steel pipe. Pipe shop fabrication topics include pipe spool pieces, bends, flanges, welding, swedged ends of pipe, end closures, flame cutting, machine cutting, beveling, machining, boring, stress relieving, radiographic inspection, magnetic or dye penetrant inspection, testing fabricated assemblies, and access holes. There is also a section on field fabrication and erection of pipework. There is a section on alloy piping, mechanical instrumentation, hangers and supports, applying thermal insulation, and also scaffold erecting and dismantling. It should be noted that the alloy piping gives percentages to adjust the carbon steel piping man-hours to apply to the alloy piping. The time estimates for scaffolding are given below (Table 30 ). 
Table 30. Man-hour estimates for scaffolding installation and dismantling (Page 1999)

\begin{tabular}{|c|c|c|c|c|c|c|}
\hline \multirow[b]{3}{*}{ Scaffold Length } & \multicolumn{6}{|c|}{ Man-hours per Section of Scaffolding } \\
\hline & \multicolumn{3}{|c|}{1 or 2 Sections High Scaffold } & \multicolumn{3}{|c|}{$\begin{array}{l}\text { Greater than } 2 \text { Sections High } \\
\text { Scaffold }\end{array}$} \\
\hline & Erect & Dismantle & Total & Erect & Dismantle & Total \\
\hline 1 or 2 sections long & 1.4 & 1.0 & 2.4 & 1.7 & 1.2 & 2.9 \\
\hline 3 to 5 sections long & 0.9 & 0.6 & 1.5 & 1.0 & 0.7 & 1.7 \\
\hline 6 or more sections long & 0.7 & 0.4 & 1.1 & 0.9 & 0.5 & 1.4 \\
\hline
\end{tabular}

A scaffold section is defined as $2.1 \mathrm{~m}$ long, $1.5 \mathrm{~m}$ wide, and $1.5 \mathrm{~m}$ high. The time estimate includes transporting the scaffolding and materials from on-site storage, erection of scaffolding (including leveling and securing), and installation of $50 \mathrm{~mm}$-thick wood planks for the walking surfaces. The dismantling includes taking the scaffolding down and transporting to on-site storage.

\section{J. S. Page, 1999, Estimator's Equipment Installation Man-Hour Manual, $3^{\text {rd }}$ edition, Gulf Professional Publishing, Houston, Texas.}

This book also gives detailed man-hours for installing various types of equipment, based on the size of the equipment. Some of the equipment items addressed in this book are boilers and heaters, compressors, conveyors, blenders, dust collectors, steam jet ejectors, fans, filters, gas scrubbers, generators, heat exchangers, hoists, pumps, centrifugal separators, surge arrestors, vessels, and tanks.

\section{Robert Snow (RS) Means Company, Inc., 1983, Means Man-Hour Standards, Knighton, Massachusetts.}

The RS Means Company is well known for its labor estimating standards, square foot estimating standards, and other cost-estimating standards. This book is older but it shows the basic approach used by the RS Means Company. The man-hour standards are divided into several categories, including site work, concrete, masonry, metals, wood and plastic, moisture protection, doors, windows, glass, finishes, furnishings, conveying systems, mechanical, and electrical. Two of the categories of greater interest for engineering systems are "mechanical" and "equipment." The mechanical section discusses piping installation up to 12-in. diameter piping. There is a section for equipment installation per ton of equipment weight, figuring in a crane operator and other craftsmen. The man-hour data are given in terms of daily output and man-hours and there is "unit" term to state the straight run length of pipe or machine to be installed, etc. The analyst must use care when working with the means data because much of the data are for residential and commercial buildings, which are not very similar to energy experiment facilities.

Cost Data On Line, Inc., 2009, Richardson's Process Plant Construction Cost Estimating Standards: The Richardson Rapid System, Pahrump, Nevada. Found at www.costdataonline.com.

This estimation program is similar to the RS Means but it is directed at chemical process plants and industrial facilities, so it is a fairly reasonable estimate for power plants and large energy experiments. The 4,000 pages of data are based on past construction activities and reflect actual times from similar projects. The construction data are given in man-hours of time to erect the plant (civil, structural, architectural, mechanical, electrical, and process equipment work) and the analyst converts man-hours to costs for cost estimating. This data set is rather costly and a copy was not obtained for the purposes of this report. Therefore, no additional descriptions can be given about components treated or how the manhour estimates are presented. 


\section{Maintainability Prediction Methods}

Several methods for predicting maintenance times have come from the military studies on maintenance. Some computer codes use this type of approach for maintenance time estimation. Two of the most-well known military approaches are described here.

Department of the Navy, 1962, Maintainability Design Criteria Handbook for Designers of Shipboard Electronic Equipment, NAVSHIPS-94324, Federal Electric Corporation, Paramus, New Jersey, April 30.

This book describes maintainability concepts, environmental effects, and concepts such as accessibility, modularization, test points, maintaining test equipment, and other issues such as illumination and standardizing components. There was other guidance information in the text as well, such as Tables 31 and 32. In conceptual design, some MTTR ranges were given for electronic equipment.

Table 31. Repair times for electronic equipment (Navy 1962)

\begin{tabular}{|l|l|l|}
\hline \multicolumn{1}{|c|}{ Type of Repair Activity } & \multicolumn{1}{|c|}{ Method of Fault Location } & \multicolumn{1}{|c|}{$\begin{array}{c}\text { MTTR } \\
\text { (hr) }\end{array}$} \\
\hline Modular replacement & Fully automatic locating & 0.2 to 0.5 \\
\hline & Partially automatic locating & 0.5 to 0.8 \\
\hline & Manual testing & 0.8 to 1.2 \\
\hline Part replacement & Fully automatic locating & 1.0 (not practical) \\
\hline & Partially automatic locating & 1.5 to 2.2 \\
\hline & Manual testing & 2.2 to 2.5 \\
\hline
\end{tabular}

Table 32. Technician experience factor used to determine staff knowledge (Navy 1962)

\begin{tabular}{|l|c|}
\hline $\begin{array}{c}\text { Technician Experience in } \\
\text { Months on the Job }\end{array}$ & $\begin{array}{c}\text { Experience } \\
\text { Factor }\end{array}$ \\
\hline 5 & 0.31 \\
\hline 10 & 0.44 \\
\hline 15 & 0.61 \\
\hline 20 & 0.74 \\
\hline 25 & 0.91 \\
\hline 30 & 1.05 \\
\hline 35 & 1.14 \\
\hline 40 or more months & 1.17 \\
\hline
\end{tabular}

The average interval between repair actions is multiplied by the experience factor to reflect staff knowledge. Often the new technicians need time-in-grade to increase their skills so that one repair session is more complete and more robust and longer lasting than when they are new to the tasks.

A CM time prediction procedure for electronic equipment conceptual design was based on Table 33. 
Table 33. Repair times used for CM predictions (Navy 1962)

\begin{tabular}{|c|c|c|c|}
\hline Replacement Item & $\begin{array}{l}\text { Localization Level } \\
\text { for Testing Features } \\
\text { Incorporated into } \\
\text { the System }\end{array}$ & $\begin{array}{l}\text { Isolation Level for } \\
\text { Testing Points in the } \\
\text { System }\end{array}$ & $\begin{array}{c}\text { MTTR } \\
\text { (hr) }\end{array}$ \\
\hline \multirow{7}{*}{ Unit } & \multirow[t]{3}{*}{ Subsystem } & Equipment & 0.7 \\
\hline & & Group & 0.6 \\
\hline & & Unit & 0.6 \\
\hline & \multirow[t]{2}{*}{ Equipment } & Group & 0.5 \\
\hline & & Unit & 0.5 \\
\hline & Group & Unit & 0.5 \\
\hline & Unit & - & 0.2 \\
\hline \multirow[t]{11}{*}{ Assembly } & \multirow[t]{4}{*}{ Subsystem } & Equipment & 1.0 \\
\hline & & Group & 0.9 \\
\hline & & Unit & 0.8 \\
\hline & & Assembly & 0.8 \\
\hline & \multirow[t]{3}{*}{ Equipment } & Group & 0.9 \\
\hline & & Unit & 0.8 \\
\hline & & Assembly & 0.8 \\
\hline & \multirow[t]{2}{*}{ Group } & Unit & 0.8 \\
\hline & & Assembly & 0.8 \\
\hline & Unit & Assembly & 0.7 \\
\hline & Assembly & - & 0.4 \\
\hline \multirow[t]{16}{*}{ Subassembly } & \multirow[t]{5}{*}{ Subsystem } & Equipment & 1.2 \\
\hline & & Group & 1.1 \\
\hline & & Unit & 1.0 \\
\hline & & Assembly & 0.9 \\
\hline & & Subassembly & 0.9 \\
\hline & \multirow[t]{4}{*}{ Equipment } & Group & 1.1 \\
\hline & & Unit & 1.0 \\
\hline & & Assembly & 0.9 \\
\hline & & Subassembly & 0.9 \\
\hline & \multirow[t]{3}{*}{ Group } & Unit & 1.0 \\
\hline & & Assembly & 0.9 \\
\hline & & Subassembly & 0.9 \\
\hline & \multirow[t]{2}{*}{ Unit } & Assembly & 0.8 \\
\hline & & Subassembly & 0.8 \\
\hline & Assembly & Subassembly & 0.8 \\
\hline & Subassembly & - & 0.5 \\
\hline \multirow[t]{13}{*}{ Part } & Subsystem & Equipment & 2.5 \\
\hline & & Group & 2.4 \\
\hline & & Unit & 2.2 \\
\hline & & Assembly & 2.2 \\
\hline & & Subassembly & 2.0 \\
\hline & & Stage & 1.8 \\
\hline & & Part & 1.6 \\
\hline & Equipment & Group & 2.4 \\
\hline & & Unit & 2.2 \\
\hline & & Assembly & 2.2 \\
\hline & & Subassembly & 2.0 \\
\hline & & Stage & 1.8 \\
\hline & & Part & 1.6 \\
\hline
\end{tabular}


Table 33. (continued)

\begin{tabular}{|l|l|l|c|}
\hline Replacement Item & $\begin{array}{c}\text { Localization Level } \\
\text { for Testing Features } \\
\text { Incorporated into } \\
\text { the System }\end{array}$ & $\begin{array}{c}\text { Isolation Level for } \\
\text { Testing Points in the } \\
\text { System }\end{array}$ & $\begin{array}{c}\text { MTTR } \\
\text { (hr) }\end{array}$ \\
\hline Part (continued) & Group & Unit & 2.2 \\
\hline & & Assembly & 2.2 \\
\hline & & Subassembly & 2.0 \\
\hline & & Stage & 1.8 \\
\hline & Part & 1.6 \\
\hline & Unit & Assembly & 2.2 \\
\hline & & Subassembly & 2.0 \\
\hline & & Stage & 1.8 \\
\hline & & Part & 1.6 \\
\hline & Assembly & Subassembly & 2.0 \\
\hline & & Stage & 1.8 \\
\hline & & Part & 1.6 \\
\hline & Subassembly & Stage & 1.8 \\
\hline & & Part & 1.6 \\
\hline & Stage & Part & 1.5 \\
\hline & Part & - & 1.0 \\
\hline & & &
\end{tabular}

In this table, parts are one or more pieces joined together that are not normally subject to disassembly and a part is simply replaced with a new part. Stages are combinations of parts that form a portion or all of a subassembly. A stage is not a replaceable part but has replaceable parts. A subassembly is two or more parts that form a portion of an assembly. An assembly is a number of parts or subassemblies that performs some function. A unit is a combination of parts, subassemblies, and assemblies that are mounted together and operate together. A unit might be a replaceable item, depending on the electronics. A group is a collection of units, assemblies, or subassemblies that is a subdivision of an equipment set or system. Equipment is defined as one or more units and necessary assemblies, subassemblies, and parts connected together (e.g., radar set, radio set). Equipment is not normally a replaceable item. A subsystem is a combination of equipment, groups, etc., that perform an operational function within a system. A subsystem would be one location of a larger system, such as one communications console of a larger communication system. An electronic system is a combination of two or more subsystems. A system is usually physically separated and achieves some function. An example of a system is a communication system consisting of multiple stations in a building or buildings.

For the table above, if the equipment in the system uses more than one type of maintenance plan (that is, a combination of replacement, localization, and isolation in the design), an estimate of the overall equipment MTTR is found by averaging individual MTTRs for the varying combinations. An example is four different maintenance plans, replaceable assemblies with failure localization features at the unit level and failure isolation test points at the assembly level, replaceable subassemblies with failure localization features at the assembly level and failure isolation test points at the subassembly level, individually replaceable parts having failure localization features at the assembly level and failure isolation test points at the stage level, and lastly individually replaceable parts with failure localization features at the unit level and failure isolation features at the stage level. Table 34 is a small table to address these four maintenance plans. 
Table 34. Overall repair time example based on four maintenance plans

\begin{tabular}{|l|l|l|l|}
\hline \multicolumn{1}{|c|}{ Replacement Item } & \multicolumn{1}{|c|}{ Localization Level } & \multicolumn{1}{c|}{ Isolation Level } & \multicolumn{1}{c|}{$\begin{array}{c}\text { MTTR } \\
\text { (hr) }\end{array}$} \\
\hline Assembly & Unit & Assembly & 0.7 \\
\hline Subassembly & Assembly & Subassembly & 0.8 \\
\hline Part & Assembly & Stage & 1.8 \\
\hline Part & Unit & Stage & 1.8 \\
\hline $\begin{array}{l}\text { Resulting MTTR of the replacement item is an average of the four maintenance plans described } \\
\text { above, the CM (replacement item) MTTR is }(0.7+0.8+1.8+1.8) / 4 \text { or } 1.3 \text { hours. This is adequate } \\
\text { for estimates during conceptual design. }\end{array}$
\end{tabular}

Department of Defense, 1966, Maintainability Prediction, MIL HDBK 472, May 24.

This is the report that is used in most computer prediction methods. This is no longer a U.S. Department of Defense handbook but it contains useful information and the CM time prediction approach is still used because it is a reasonable approach.

The basic MTTR is found by decomposition into its basic elements and estimating time needed for each element. The equation below illustrates this:

$\operatorname{MTTR}=\mathrm{T}_{\mathrm{P}}+\mathrm{T}_{\mathrm{FI}}+\mathrm{T}_{\mathrm{D}}+\mathrm{T}_{\mathrm{I}}+\mathrm{T}_{\mathrm{R}}+\mathrm{T}_{\mathrm{A}}+\mathrm{T}_{\mathrm{CO}}+\mathrm{T}_{\mathrm{ST}}$

where

$\mathrm{T}_{\mathrm{P}}=$ average preparation time to make ready for the repair activity

$\mathrm{T}_{\mathrm{Fl}}=$ average fault isolation time

$\mathrm{T}_{\mathrm{D}}=$ average component disassembly time

$\mathrm{T}_{1}=$ average interchange time for part replacement

$\mathrm{T}_{\mathrm{R}}=$ average reassembly time

$\mathrm{T}_{\mathrm{A}}=$ average alignment time

$\mathrm{T}_{\mathrm{CP}}=$ average component checkout time (post-repair test)

$\mathrm{T}_{\mathrm{ST}}=$ average startup time to put component back on-line

This handbook also gives some standard times for electronics-based equipment. The elements described in Table 35 below are the sizes found in electronics cabinets or modules. 
Table 35. Repair times for electronics-based equipment (Defense 1966)

\begin{tabular}{|l|c|c|c|}
\hline \multirow{2}{*}{\multicolumn{1}{c|}{ Element Description }} & \multicolumn{3}{|c|}{ Standard Average Times } \\
\cline { 2 - 4 } & $\begin{array}{c}\text { Remove } \\
\text { (min) }\end{array}$ & $\begin{array}{c}\text { Replace } \\
\text { (min) }\end{array}$ & $\begin{array}{c}\text { Interchange } \\
\text { (min) }\end{array}$ \\
\hline Screw fastener & 0.16 & 0.26 & 0.42 \\
\hline Hex-head fastener & 0.17 & 0.43 & 0.60 \\
\hline Nut or bolt & 0.34 & 0.44 & 0.78 \\
\hline Spring clip latch & 0.04 & 0.03 & - \\
\hline Terminal post per lead & 0.22 & 0.64 & - \\
\hline $\begin{array}{l}\text { Printed circuit board discrete } \\
\text { terminal connection }\end{array}$ & 0.14 & 0.17 & 0.08 \\
\hline $\begin{array}{l}\text { Quick release co-axial } \\
\text { connector }\end{array}$ & 0.04 & 0.04 & 0.10 \\
\hline Strip insulation from signal wire & & & 0.27 \\
\hline Crimp lugs & & & 0.22 \\
\hline Soldering terminal posts & & 0.03 & 0.07 \\
\hline Panel or door or cover & 0.04 & 0.11 & 0.21 \\
\hline Display lamp & 0.10 & & - \\
\hline
\end{tabular}

These times can be used to estimate the repair times for electronic equipment. Sets of mathematical formulas are given in the handbook to use when estimating these times from representative data from a facility or a repair shop. Some of these data came from the 1970 report RADC-TR-70-89, Maintainability Prediction and Demonstration Techniques.

For MTTR estimates in the early stages of electronics system design, MIL HDBK 472 also gives some average CM times to use in giving a general estimate of CM MTTR for electronic parts. The table of these times is given in Figure 3 below. The definitions of part, stage, subassembly, assembly, etc., are given earlier in this chapter. The analyst selects the proper column on the left side of the table, then tracks down to the appropriate row. From the appropriate row, the average time values for diagnosis, replacement, and test are read from the right side of the table. An example is that the analyst determines that a power supply is at the unit level (number 5 on the left side of the table), and that failure localization is effective at the equipment level in the power supply. Therefore, the times for localization and isolation are $0.056+1.417$ hours, for a total diagnosis time of 1.473 hours-likewise for replacement $(0.165+0.262 \mathrm{hr})$ and testing $(0.045+0.158 \mathrm{hr})$. 


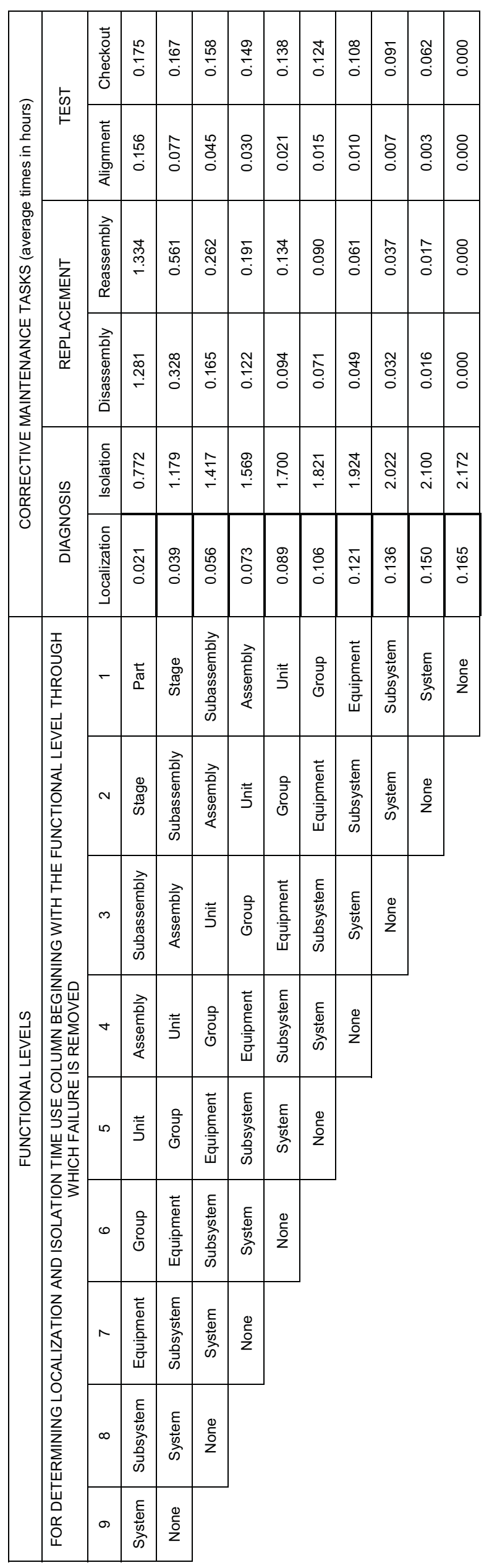

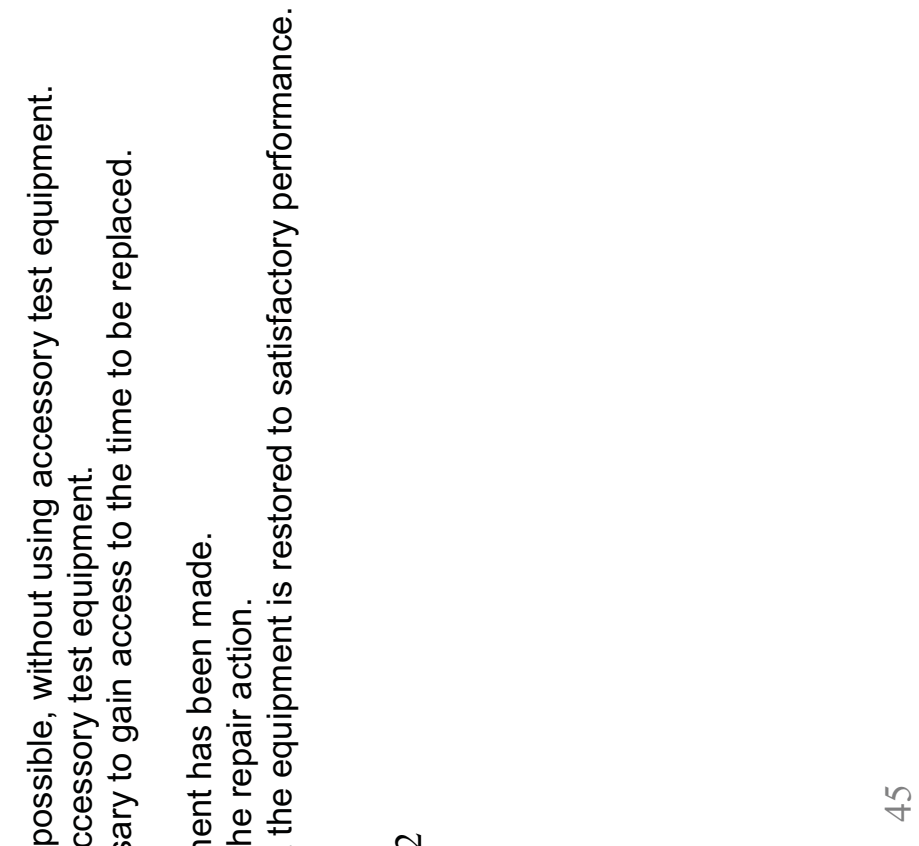
응 +

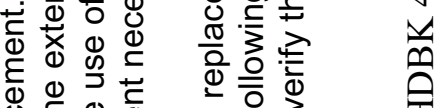

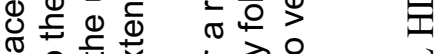

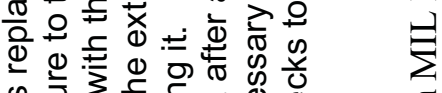

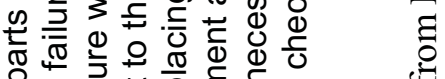

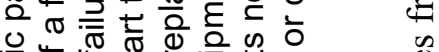

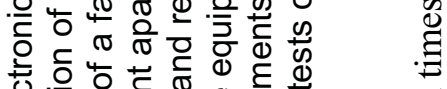
过

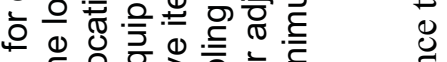

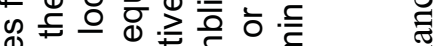

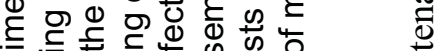
잉 $\Phi$

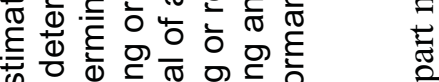
ळ 0 过

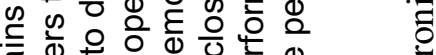

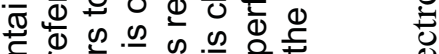

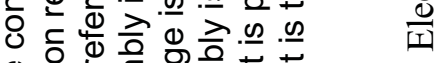

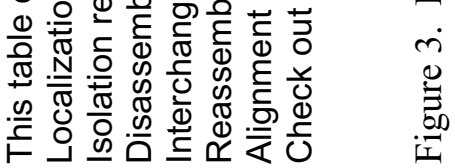


There are other approaches that have been developed as well. The Methods Time Measurement and the Maynard Operation Sequence Technique are two of the better known systems that divide maintenance actions into the basic body actions needed to complete a task (reach, move, turn, grasp, eye travel, body positioning, etc.). The times needed to perform these motions or movements are summed to give the overall time required. These are very exact systems and much data are needed (such as the motion distances must be accurately measured). If not exact, then errors can creep in to the time estimates. These methods tend to be best for highly repetitive activities such as short-cycle operations and general industrial work on assembly lines rather than unique repairs. For less repetitive operations and for maintenance where workers must assume awkward positions to reach equipment, these methods may not give optimum results.

\section{J. Rose, J. J. Voytko, and J. A. Davolt, 1984, Maintainability Time Standards for Electronic Equipment, RADC-TR-84-165, July.}

This report is a methods time measurement approach that gives the individual times for steps in electronics repair. There are also multiplicative factors given to account for personal hygiene and comfort, fatigue in various settings (shop or field), and logistic delays. This method can be useful for work on electronics, such as control systems, when actual component replacement is necessary. These approaches have been expanded with expert opinion to apply to other equipment besides electronics found in control systems, communications, radar, and other military systems. Extrapolations to mechanical, electrical, and instrumentation have been performed.

More recent work has used virtual environments to assess maintenance access, tool and part clearance, and 3-dimensional space needs for performing maintenance (Badler 2002). Badler discusses maintenance through access hatches on the F-22 fighter jet, including how to get spare parts through the access hatches. The virtual human in a computer-generated maintenance task has been taken a step further, with computer modeling of the time to perform a maintenance task as a series of methods time measurement steps (Kang 2012). Kang's test of people in an actual mockup that was also modeled in virtual reality showed good comparison for basic human motions (stride, crouch, hand operations such as grasp, push, pull, etc.), the computer and human being times were within $1 \%$ of each other. The tool positioning and cranking a lever had more variation, up to $10 \%$, with the computer typically calculating less time than the human subject required for the action. These virtual methods are intriguing and can perhaps give good initial estimates of needed repair times but they do require a high level of design detail to be modeled by the computer. With that need, this approach is costly to prepare. 


\section{Maintenance in Radiation Fields and Some Multipliers for Maintenance Times}

The radiation dose goal or administrative control dose levels for workers in radiation areas of a facility tend to be set conservatively lower than legal limits (Prince 2012). Facility dose goals vary. For example, the ITER dose goal is $2.5 \mathrm{mSv} / \mathrm{yr}(0.25 \mathrm{rem} / \mathrm{yr})$ for a radiation worker, and a collective dose limit of 500 person-mSv/yr (50 person-rem/yr) is also adopted (Taylor 2012).

The description of JET radiological safety indicates that a dose goal per repair activity is established (Patel 1999); some quoted values were $2 \mathrm{mSv}$ and $3 \mathrm{mSv}$ per person for multi-day repair tasks. Patel indicates that in-vessel fields of 5 and $6 \mathrm{mSv} / \mathrm{hr}$ necessitate remote handling, which is obvious with their rather low facility annual exposure limit per person of $5 \mathrm{mSv} / \mathrm{yr}(500 \mathrm{mrem} / \mathrm{yr})$. The $5 \mathrm{mSv} / \mathrm{yr}$ is below $25 \%$ of the statutory annual limit. Hot spots on the exterior of the JET machine could reach $0.6 \mathrm{mSv} / \mathrm{hr}$ $(60 \mathrm{mrem} / \mathrm{hr}$ ) on contact in the hands-on maintenance radiation areas. Patel (2001) describes some of the allowed radiation fields for worker hands-on exposure in the JET vessel; in general the dose rates varied from 0.017 to $0.35 \mathrm{mSv} / \mathrm{hr}$ (1.7 to $35 \mathrm{mrem} / \mathrm{hr}$ ) over 4 years of JET shutdowns.

The INL limit for hands-on radiation work is $<2 \mathrm{mSv} / \mathrm{hr}(<200 \mathrm{mrem} / \mathrm{hr})$. Above that level, remote handling tools are used (INL 2010). In general, the contact handled radioactive material limits are external dose rates of $\leq 2 \mathrm{mSv} / \mathrm{hr}(200 \mathrm{mrem} / \mathrm{hr})$ at contact and $\leq 1 \mathrm{mSv} / \mathrm{hr}(100 \mathrm{mrem} / \mathrm{hr})$ at arm's length of $30 \mathrm{~cm}$ (Brown 2004). These values are sensible because worker annual exposure goals are low, so high dose rates would cause the radiation worker to not be allowed to work in radiation fields for many hours of the year. Dose rates are kept as low as possible. The need to use remote tools and remote handling is found at these relatively modest dose rates.

There are a few "rules of thumb" used at the INL for estimating hands-on maintenance time in various situations (Cadwallader 1996):

- Work performed in full anti-contamination clothing (hood, gloves, booties, coveralls) requires $2 \times$ the normal task time needed without this protective clothing. Recall in Section 2 that Swenson (2000) also used a 1.5 to $2 \times$ increase in the maintenance time in a radioactive contamination area, so this $2 \times$ appears to be a reasonable value. Work performed using supplied breathing air requires $3 \times$ longer than normal task time.

- Work performed in 2 or 3 shift operations is $1.2 \times$ longer time than the normal one-shift task time because of shift-to-shift task coordination issues; but nonetheless, applying more people in several shifts to the tasks results in shorter calendar time.

- For operations requiring remote manipulators such as mobile tele-operated manipulators in a facility, the work can take 5 to $8 \times$ longer than for hands-on maintenance. An experienced operator can perform at the $5 \times$ level, while less experienced operators (or issues of confined space or congested access) would be closer to a factor of $8 \times$. The INL made use of remote-operated manipulators to perform maintenance tasks on the fission fuel Chemical Processing Plant systems. Remote maintenance almost always requires operator training and rehearsal, while hands-on maintenance does not. The INL engineers practiced rehearsals in other facilities and in mock-ups before performing the maintenance on the chemical plant.

- For hot cells with master-slave manipulators, the basic assumption is a 10 to 1 ratio of time needed to perform a task in-cell versus the same task with hands-on work (Lind 2012). This discussion is for master-slave manipulators with modest ( 4.5 up to $22 \mathrm{~kg}$ ) load limits. An experienced operator can do everything with the set of end effectors that a maintainer can do with his hands; it is more challenging work with the manipulators. 
Protective clothing is worn as a measure of radiological or toxicological protection for workers, but the clothing — particularly gloves — reduces efficiency (Teixeira 1990; Berkhout 1992). One study showed that full protective clothing increased maintenance task time on military missile maintenance by an average of $45 \%$ (Waugh 1984). For fusion, in-vessel maintenance with anti-contamination and chemical protective "bubble suit" clothing, such as worn at JET in the 1993 divertor installation to protect against beryllium dust exposure (Russ 1992; Scott 1993), would also reduce worker efficiency. Time increases from past in-vessel maintenance that required only respirators, gloves, and coveralls for protection is expected at some value similar to Waugh (1984). Other issues include erecting and removing temporary shielding, such as lead sheets or leaded sandbags, setting up radiological boundary areas for donning and doffing anti-contamination clothing, and setting up radiological survey stations for workers to frisk after leaving radiological areas. All of these acts require time. 


\section{9. $\quad$ References}

Badler, N. I., C. A. Erignac, and Y. Liu, 2002, "Virtual Humans for Validating Maintenance Procedures," Communications of the ACM, 45, July, pp. 57-63.

Berkhout, J., et al., 1992, Gloved Operator Performance Study, NTIS accession number AD-A256 894, Human Engineering Laboratory, Aberdeen Proving Ground, September.

Brown, R. L., 2004, Contact Handled-Transuranic Waste High Dose Rate Issue Resolution Study, RPP-21475, CH2M Hill Hanford Group, Inc., August.

Cadwallader, L. C., 1996, Determining Representative Hands-on Maintenance Times for ITER, ITER Engineering Design File ITER/US/96/TE/SA-01, U.S. Home Team, Idaho National Engineering Laboratory, February 23.

Hashemian, H. M., D. W. Mitchell, K. M. Petersen, and C. S. Shell, 1993, Validation of Smart Sensor Technologies for Instrument Calibration Reduction in Nuclear Power Plants, NUREG/CR-5903, NRC, Washington DC.

INL, 2010, Preliminary Hazard Analysis for the Remote-Handled Low-Level Waste Disposal Facility, INL/EXT-07-12903, Rev. 2, Idaho National Laboratory, February.

Kang, L., D. Zhou, and C. Lv, 2012, “A New Maintenance Time Measurement Method by Virtual Reality," Journal of Theoretical and Applied Information Technology, 43, September, pp. 74-81.

Lind, R. P., 2012, hot cell operations engineer, Idaho National Laboratory, private communication, March 6.

Lobner, P., C. Donahoe, C. Cavallin, 1990, Overview and Comparison of U.S. Commercial Nuclear Power Plants, NUREG/CR-5640, NRC, September, Table 7-5, Table 10-8.

Patel, B., D. C. Campling, P. Macheta, K. Sandland, and P. A. Schofield, 1999, "Health Physics Aspects of Tritium Operation at JET,” Fusion Engineering and Design, 47, pp. 267-283.

Patel, B., P. Edwards, S. Popovichev, and P. Schofield, 2001, "Accrued and Expected Radiation Doses to Personnel during Manual Access to the JET Vessel," Fusion Engineering and Design, 58-59, pp. 1071-1075.

Prince, R., 2012, Radiation Protection at Light Water Reactors, Springer Verlag, Berlin, pg. 248.

Russ, R. M., A. D. Haigh, and S. J. Booth, 1992, "Beryllium Safety at JET," Proceedings of the $14^{\text {th }}$ IEEE/NPSS Symposium on Fusion Engineering, September 30-October 3, 1991, San Diego, California, IEEE, pp. 596-599.

Scott, S. M., et al., 1993, "Decontamination of the JET Vacuum Vessel from Beryllium and Tritium," Fusion Technology 1992, Proceedings of the $17^{\text {th }}$ Symposium on Fusion Technology, September 1418, 1992, Rome, Italy, Elsevier Science Publishers, pp. 1216-1219.

Swenson, C. E., 2000, FMEA/RAM Analysis for the Multi-Canister Overpack Handling Machine, SNF-6449, Fluor Hanford, June. 
Taylor, N., C. Alejaldre, P. Cortes, 2012, "Progress in the Safety and Licensing of ITER," presented at the $20^{\text {th }}$ Topical Meeting on the Technology of Fusion Energy, Nashville, Tennessee, August 26-30, 2012. To be published in Fusion Science and Technology.

Teixeira, R. A., and C. K. Bensel, 1990, The Effects of Chemical Protective Gloves and Glove Liners on Manual Dexterity, NATICK/TR-91/002, U.S. Army Natick Research, Development and Engineering Center, Natick, Massachusetts, December.

Tung, Y.-K., B.-C. Yen, C. Melching, 2006, Hydrosystems Engineering Reliability Assessment and Risk Analysis, McGraw-Hill Book Company, New York, Chapter 5.

Waugh, J. D., and P. W. Kilduff, 1984, Missile Component Repair while Wearing NBC Protective Clothing, SR-30646, ADD703233, U.S. Army Human Engineering Laboratory, January. 